\title{
Luminescence Solvato- and Vapochromism of Alkynyl-Phosphine Copper Clusters
}

\author{
Ilya S. Krytchankou, ${ }^{\dagger}$ Igor O. Koshevoy, ${ }^{*}{ }^{\ddagger}$ Vladislav V. Gurzhiy, ${ }^{\S}$ Vladimir A. Pomogaev, ${ }^{\dagger, \|}$ \\ and Sergey P. Tunik*, \\ ${ }^{\dagger}$ St. Petersburg State University, Institute of Chemistry, Universitetskii pr. 26, 198504 St. Petersburg, Russia \\ ${ }^{\ddagger}$ University of Eastern Finland, Department of Chemistry, 80101 Joensuu, Finland \\ ${ }^{\S}$ St. Petersburg State University, Institute of Earth Sciences, Universitetskaya nab. 7-9, 199034 St. Petersburg, Russia \\ "Tomsk State University, Lenina pr. 36, 634050 Tomsk, Russia
}

Supporting Information

\begin{abstract}
The reaction of $\left[\mathrm{Cu}(\mathrm{NCMe})_{4}\right]\left[\mathrm{PF}_{6}\right]$ with aromatic acetylenes $\mathrm{HC}_{2} \mathrm{R}$ and triphosphine 1,1,1-tris(diphenylphosphino)methane in the presence of $\mathrm{NEt}_{3}$ results in the formation of hexanuclear $\mathrm{Cu}(\mathrm{I})$ clusters with the general formula $\left[\mathrm{Cu}_{6}\left(\mathrm{C}_{2} \mathrm{R}\right)_{4}\left\{\left(\mathrm{PPh}_{2}\right)_{3} \mathrm{CH}\right\}_{2}\right]\left[\mathrm{PF}_{6}\right]_{2} \quad\left(\mathrm{R}=4-\mathrm{X}-\mathrm{C}_{6} \mathrm{H}_{4}\right.$ (1-5) and $\mathrm{C}_{5} \mathrm{H}_{4} \mathrm{~N}(6) ; \mathrm{X}=\mathrm{NMe}_{2}$ (1), OMe (2), H (3), $\mathrm{Ph}$ (4), $\left.\mathrm{CF}_{3}(5)\right)$. The structural motif of the complexes studied consists of a $\mathrm{Cu}_{6}$ metal core supported by two phosphine ligands and stabilized by $\sigma$ - and $\pi$-coordination of the alkynyl fragments (together with coordination of pyridine nitrogen atoms in cluster 6). The solid state structures of complexes 2-6 were determined by single crystal XRD analysis. The structures of the complexes in solution were elucidated by ${ }^{1} \mathrm{H},{ }^{31} \mathrm{P},{ }^{1} \mathrm{H}-{ }^{1} \mathrm{H}$ COSY NMR spectroscopy, and ESI mass spectrometry. Clusters 1-6 exhibit moderately strong phosphorescence in the solid state with quantum yields up to $17 \%$. Complexes 1-5 were found to form solvates (acetone, acetonitrile) in the solid state. The coordination of loosely bound solvent molecules strongly affects emission characteristics and leads to solvato- and vapochromic behavior of the clusters. Thus, solventfree and acetonitrile solvated forms of 3 demonstrate contrasting emission in orange $(615 \mathrm{~nm})$ and blue $(475 \mathrm{~nm})$ regions, respectively. The computational studies show that alkynyl-centered IL transitions mixed with those of $\mathrm{MLCT}_{\text {between }}$ the $\mathrm{Cu}_{6}$ metal core and the ligand environment play a dominant role in the formation of excited states and can be considerably modulated by weakly coordinating solvent molecules leading to luminescence vapochromism.
\end{abstract}

\section{INTRODUCTION}

The study of coinage metal complexes continues to consistently be one of the forefront areas of organometallic chemistry over the past three decades. A large variety of $\mathrm{Cu}, \mathrm{Ag}$, and $\mathrm{Au}$ species have found applications in catalysis and formed a basis for new functional materials with unusual physical characteristics. In particular, the attractive photophysical behavior of copper subgroup metal complexes, which includes highly efficient and tunable luminescence, significantly stimulates preparative efforts in the search for novel emissive objects. ${ }^{1}$ An intrinsic feature of the closed-shell $\mathrm{d}^{10}$ compounds (i.e., those of $\mathrm{M}^{\mathrm{I}}$ ions, $\mathrm{M}=\mathrm{Cu}, \mathrm{Ag}, \mathrm{Au}$ ) is a strong tendency to form extended networks of metallophilic bonds, which facilitate the assembly of multinuclear metal cores. ${ }^{2}$ In addition to the fascinating structural diversity of these aggregates, reaching supramolecular and nanoscale levels, the metal-metal interactions are often responsible for a dramatic change or emergence of photoemission and nonlinear optical properties. ${ }^{3}$ Moreover, a relative weakness of the metallophilic bonds (the strength of which is comparable to that of hydrogen bonding), ${ }^{4}$ stands behind the easiness of their modulation and, consequently, sensitivity to certain external stimuli (chemical vapors, mechanical force, temperature). ${ }^{1 \mathrm{~h}, 3 \mathrm{e}, \mathrm{f}, \mathrm{h}, 5}$ The latter phenomena give rise to stimuli-responsive materials demonstrating a detectable alteration of the physical properties (e.g., in absorption or, more preferably, emission spectra), ultimately capable of, e.g., selective luminescent chemo- or ratiometric sensing both in solution and in the solid state. ${ }^{3 \mathrm{a}, \mathrm{b}, 5 \mathrm{f}, \mathrm{6}}$

The metallophilic interactions can be effectively supported by the multidentate ligands, which are able to bridge a few adjacent metal centers, thus promoting self-assembly of multinuclear clusters. In this respect, the alkynyl moiety was found to be a superior bridging group for the $\mathrm{d}^{10}$ ions due to its pronounced tendency for simultaneous bonding through $\sigma$ - and $\pi$-coordination modes. ${ }^{2 \mathrm{~b}, 7}$ No less important is that the $-\mathrm{C} \equiv$ CR groups provide a facile opportunity for delicate modification of their electronic characteristics, opening wide

Received: April 27, 2015

Published: August 11, 2015 
possibilities for fine-tuning of photophysical properties of the cluster complexes. $^{8}$

As homoleptic copper alkynyl complexes are typically polymeric, suitable ancillary phosphine ligands are normally introduced to generate the molecular entities of different structural types depending on the stereochemistry of the coordination environment. ${ }^{2 \mathrm{~b}}$

Interestingly, despite the environmental friendliness and high natural abundance of copper (i.e., low cost), $\mathrm{Cu}^{\mathrm{I}}$ compounds are the least studied class among the coinage metal alkynyl clusters in comparison to the numerous polynuclear gold(I), silver(I), and heterometallic $\mathrm{Au}-\mathrm{Cu}$ and $\mathrm{Au}-\mathrm{Ag}$ species, presumably due to the typically higher coordination number of $\mathrm{Cu}^{\mathrm{I}}$ ion $(\mathrm{C} . \mathrm{N} .=4)$ than those of $\mathrm{d}^{10}$ relatives $\mathrm{Au}^{\mathrm{I}}$ and $\mathrm{Ag}^{\mathrm{I}}$ (C.N. = 2-4). The notable examples of homometallic clusters built of $\{\mathrm{CuC} \equiv \mathrm{CR}\}$ units include the dinuclear diamond-like complexes $\left.\left[\mathrm{Cu}_{2} \text { (phosphine }\right)_{x}\left(\mu-\eta^{1}-\mathrm{C} \equiv \mathrm{CPh}\right)_{2}\right],{ }^{9}$ a family of trinuclear clusters $\left[\mathrm{Cu}_{3}(\mu \text {-dppm })_{3}(\mathrm{C} \equiv \mathrm{CR})_{2}\right]^{+}(\mathrm{dppm}=$ diphenylphosphinomethane), for which systematic variation of the electronic structures and investigations of the photophysical properties were carried out, ${ }^{10}$ and the tetracopper complexes $\left[\mathrm{Cu}_{4}(\text { phosphine })_{x}(\mathrm{C} \equiv \mathrm{CR})_{y}\right]$ of various topologies determined by the phosphines. ${ }^{11}$ These examples clearly show an important role of the phosphines in the formation of a particular metal framework and their photophysical characteristics.

Pursuing the development of novel luminophores based on $\mathrm{Cu}^{\mathrm{I}}$ ions, we intended to expand the class of copper alkynyl clusters through the employment of multidentate phosphine ligands, which have not been previously used for the construction of such homometallic species.

Herein, we report on the preparation of novel hexanuclear luminescent $\mathrm{Cu}^{\mathrm{I}}$ alkynyl complexes stabilized by the triphosphine tris(diphenylphosphino)methane ligand (tppm), their structural characterization in solution and in solid state, together with detailed photophysical investigations supported by theoretical DFT calculations of the electronic structures.

\section{EXPERIMENTAL SECTION}

General Comments. All reagents and solvents were used as received. The $1 \mathrm{D}{ }^{1} \mathrm{H},{ }^{31} \mathrm{P}$, and $2 \mathrm{D}{ }^{1} \mathrm{H}-{ }^{1} \mathrm{H}$ COSY NMR spectra were recorded on Bruker Ascend 400 spectrometer. Mass spectra were measured on a Bruker APEX-Qe ESI FT-ICR instrument in $\mathrm{ESI}^{+}$ mode. Microanalyses were carried out on an elemental analyzer Euro EA3028-NT.

Synthesis of Complexes 1-6. $\left[\mathrm{Cu}(\mathrm{NCMe})_{4}\right]\left(\mathrm{PF}_{6}\right)(56 \mathrm{mg}, 0.15$ $\mathrm{mmol}$ ) and 1,1,1-tris(diphenylphosphino)methane (29 mg, 0.05 $\mathrm{mmol}$ ) were dissolved in acetone $\left(5 \mathrm{~cm}^{3}\right)$. A nearly clear colorless reaction mixture was stirred for $10 \mathrm{~min}$ and then was treated with a solution of the appropriate alkyne $(0.1 \mathrm{mmol})$ in acetone $\left(2 \mathrm{~cm}^{3}\right)$ followed by the addition of $\mathrm{NEt}_{3}$ ( 2 drops, $\sim 0.2 \mathrm{mmol}$ ) to give colored solutions (from yellow to deep red). The reaction mixture was stirred for $15 \mathrm{~min}$, filtered through a pad of Celite, and recrystallized by gasphase diffusion of pentane into an acetone solution of the corresponding complex at $+5{ }^{\circ} \mathrm{C}$.

$\left[\mathrm{Cu}_{6}\left(\mathrm{C}_{2} \mathrm{C}_{6} \mathrm{H}_{4} \mathrm{NMe}_{2}\right)_{4}\left\{\left(\mathrm{PPh}_{2}\right)_{3} \mathrm{CH}_{2}\right]\left(\mathrm{PF}_{6}\right)_{2}\right.$ (1). Deep-red crystals $(92 \%)$. ESI MS $(\mathrm{m} / z):\left[\mathrm{Cu}_{3}\left(\mathrm{C}_{2} \mathrm{C}_{6} \mathrm{H}_{4} \mathrm{NMe}_{2}\right)_{2}\left\{\left(\mathrm{PPh}_{2}\right)_{3} \mathrm{CH}\right\}\right]^{+}$ 1047.12 (calcd 1047.11); [M $]^{2+} 1047.12$ (calcd 1047.11). ${ }^{31} \mathrm{P}\left\{{ }^{1} \mathrm{H}\right\}$ NMR $\left(\mathrm{CD}_{3} \mathrm{CN}, 298 \mathrm{~K}\right): \delta 5.9$ (s, $6 \mathrm{P}$, phosphine), -144.6 (sept, $2 \mathrm{P}$, $\left.\mathrm{PF}_{6}\right) .{ }^{1} \mathrm{H}$ NMR $\left(\mathrm{CD}_{3} \mathrm{CN}, 298 \mathrm{~K}\right): \delta\left\{\left(\mathrm{PPh}_{2}\right)_{3} \mathrm{CH}\right\} 7.78\left(\mathrm{~m}-\left(\mathrm{ABXX}^{\prime}\right)\right.$, $\left.{ }^{3} J_{\mathrm{P}, \mathrm{H}}=12,{ }^{3} J_{\mathrm{H}, \mathrm{H}}=8 \mathrm{~Hz}, 24 \mathrm{H}, o-\mathrm{H}\right), 6.93\left(\mathrm{t},{ }^{3} J_{\mathrm{H}, \mathrm{H}}=7 \mathrm{~Hz}, 12 \mathrm{H}, p-\mathrm{H}\right)$, $6.74\left(\mathrm{dd},{ }^{3} J_{\mathrm{H}, \mathrm{H}}=8 \mathrm{~Hz},{ }^{3} J_{\mathrm{H}, \mathrm{H}}=7 \mathrm{~Hz}, 24 \mathrm{H}, m-\mathrm{H}\right), 6.01\left(\mathrm{q},{ }^{3} J_{\mathrm{P}, \mathrm{H}}=8 \mathrm{~Hz}\right.$, $2 \mathrm{H}, \mathrm{P}-\mathrm{CH}) ;\left\{\mathrm{C}_{2} \mathrm{C}_{6} \mathrm{H}_{4} \mathrm{NMe}_{2}\right\} 7.25\left(\mathrm{~d},{ }^{3} \mathrm{~J}_{\mathrm{H}, \mathrm{H}}=9 \mathrm{~Hz}, 8 \mathrm{H}, o-\mathrm{H}\right), 6.60(\mathrm{~d}$, $\left.{ }^{3} J_{\mathrm{H}, \mathrm{H}}=9 \mathrm{~Hz}, 8 \mathrm{H}, m-\mathrm{H}\right), 2.91\left(\mathrm{~s}, 24 \mathrm{H}, \mathrm{CH}_{3}\right)$. Anal. Calcd for
$\mathrm{Cu}_{6} \mathrm{C}_{114} \mathrm{H}_{102} \mathrm{~F}_{12} \mathrm{~N}_{4} \mathrm{P}_{8}: \mathrm{C}, 57.41 ; \mathrm{H}, 4.31 ; \mathrm{N}, 2.35$. Found: C, 57.32; H, $4.38 ; \mathrm{N}, 2.26$

$\left[\mathrm{Cu}_{6}\left(\mathrm{C}_{2} \mathrm{C}_{6} \mathrm{H}_{4} \mathrm{OMe}\right)_{4}\left\{\left(\mathrm{PPh}_{2}\right)_{3} \mathrm{CH}\right\}_{2}\right]\left(\mathrm{PF}_{6}\right)_{2}$ (2). Pale yellow crystals (94\%). Single crystals of 2 suitable for XRD study were obtained by gas-phase diffusion of pentane into its dichloromethane solution at +5 ${ }^{\circ} \mathrm{C}$ (unsolvated form, 2A) or gas-phase diffusion of diethyl ether into $\mathrm{MeCN}$ solution at $+5{ }^{\circ} \mathrm{C}$ (acetonitrile-solvated form, 2B). ESI MS $(\mathrm{m} / z):\left[\mathrm{Cu}_{3}\left(\mathrm{C}_{2} \mathrm{C}_{6} \mathrm{H}_{4} \mathrm{OMe}\right)_{2}\left\{\left(\mathrm{PPh}_{2}\right)_{3} \mathrm{CH}\right\}\right]^{+} 1021.06$ (calcd 1021.05); $[\mathrm{M}]^{2+} 1021.06$ (calcd 1021.05). ${ }^{31} \mathrm{P}\left\{{ }^{1} \mathrm{H}\right\}$ NMR $\left(\mathrm{CD}_{3} \mathrm{CN}, 298 \mathrm{~K}\right): \delta$ 6.3 (s, $6 \mathrm{P}$, phosphine), -144.6 (sept, $\left.2 \mathrm{P}, \mathrm{PF}_{6}\right) .{ }^{1} \mathrm{H}$ NMR $\left(\mathrm{CD}_{3} \mathrm{CN}\right.$, $298 \mathrm{~K}): \delta\left\{\left(\mathrm{PPh}_{2}\right)_{3} \mathrm{CH}\right\} 7.75\left(\mathrm{~m}-\left(\mathrm{ABXX}^{\prime}\right),{ }^{3} J_{\mathrm{P}, \mathrm{H}}=12,{ }^{3} J_{\mathrm{H}, \mathrm{H}}=8 \mathrm{~Hz}, 24\right.$ $\mathrm{H}, o-\mathrm{H}), 6.94\left(\mathrm{t},{ }^{3} J_{\mathrm{H}, \mathrm{H}}=7 \mathrm{~Hz}, 12 \mathrm{H}, p-\mathrm{H}\right), 6.74\left(\mathrm{dd},{ }^{3} J_{\mathrm{H}, \mathrm{H}}=8 \mathrm{~Hz},{ }^{3} J_{\mathrm{H}, \mathrm{H}}\right.$ $=7 \mathrm{~Hz}, 24 \mathrm{H}, m-\mathrm{H}), 6.05\left(\mathrm{q},{ }^{3} J_{\mathrm{P}, \mathrm{H}}=7 \mathrm{~Hz}, 2 \mathrm{H}, \mathrm{P}-\mathrm{CH}\right)$; $\left\{\mathrm{C}_{2} \mathrm{C}_{6} \mathrm{H}_{4} \mathrm{OMe}\right\} 7.32\left(\mathrm{~d},{ }^{3} \mathrm{~J}_{\mathrm{H}, \mathrm{H}}=8 \mathrm{~Hz}, 8 \mathrm{H}, o-\mathrm{H}\right), 6.84\left(\mathrm{~d},{ }^{3} \mathrm{~J}_{\mathrm{H}, \mathrm{H}}=8 \mathrm{~Hz}\right.$, $8 \mathrm{H}, m-\mathrm{H}), 3.76\left(\mathrm{~s}, 12 \mathrm{H}, \mathrm{CH}_{3}\right)$. Anal. Calcd for $\mathrm{Cu}_{6} \mathrm{C}_{110} \mathrm{H}_{90} \mathrm{~F}_{12} \mathrm{O}_{4} \mathrm{P}_{8}$ : C, 56.63; H, 3.89. Found: C, 56.70; H, 3.95.

$\left[\mathrm{Cu}_{6}\left(\mathrm{C}_{2} \mathrm{Ph}\right)_{4}\left\{(\mathrm{PPh})_{3}\right)_{3} \mathrm{CH}_{2}\right]\left(\mathrm{PF}_{6}\right)_{2}$ (3). Yellow crystals (95\%). Single crystals of 3 suitable for XRD study were obtained by gas-phase diffusion of pentane into its dichloromethane solution at $+5{ }^{\circ} \mathrm{C}$ (unsolvated form, $3 \mathrm{~A}$ ) or gas-phase diffusion of pentane into acetone solution or diethyl ether into $\mathrm{MeCN}$ solution at $+5{ }^{\circ} \mathrm{C}$ (acetonesolvated 3B and acetonitrile-solvated 3C forms, respectively). ESI MS $(\mathrm{m} / z):\left[\mathrm{Cu}_{3}\left(\mathrm{C}_{2} \mathrm{Ph}\right)_{2}\left\{\left(\mathrm{PPh}_{2}\right)_{3} \mathrm{CH}\right\}\right]^{+} 961.04$ (calcd 961.03); $[\mathrm{M}]^{2+}$ 961.04 (calcd 961.03); $\left[\mathrm{M}+\mathrm{HCO}_{2}\right]^{+} 1967.07$ (calcd 1967.06); [M $\left.+\mathrm{PF}_{6}\right]^{+} 2067.03$ (calcd 2067.02). ${ }^{31} \mathrm{P}\left\{{ }^{1} \mathrm{H}\right\} \mathrm{NMR}\left(\mathrm{CD}_{3} \mathrm{CN}, 298 \mathrm{~K}\right): \delta$ 6.7 (s, $6 \mathrm{P}$, phosphine), -144.6 (sept, $\left.2 \mathrm{P}, \mathrm{PF}_{6}\right) .{ }^{1} \mathrm{H}$ NMR $\left(\mathrm{CD}_{3} \mathrm{CN}\right.$, $298 \mathrm{~K}): \delta\left\{\left(\mathrm{PPh}_{2}\right)_{3} \mathrm{CH}\right\} 7.74\left(\mathrm{~m}-\left(\mathrm{ABXX}^{\prime}\right),{ }^{3} J_{\mathrm{P}, \mathrm{H}}=12,{ }^{3} J_{\mathrm{H}, \mathrm{H}}=8 \mathrm{~Hz}, 24\right.$ $\mathrm{H}, o-\mathrm{H}), 6.93\left(\mathrm{t},{ }^{3} J_{\mathrm{H}, \mathrm{H}}=7 \mathrm{~Hz}, 12 \mathrm{H}, p-\mathrm{H}\right), 6.72\left(\mathrm{dd},{ }^{3} J_{\mathrm{H}, \mathrm{H}}=8 \mathrm{~Hz},{ }^{3} J_{\mathrm{H}, \mathrm{H}}\right.$ $=7 \mathrm{~Hz}, 24 \mathrm{H}, m-\mathrm{H}), 6.06\left(\mathrm{q},{ }^{3} J_{\mathrm{P}, \mathrm{H}}=7 \mathrm{~Hz}, 2 \mathrm{H}, \mathrm{P}-\mathrm{CH}\right) ;\left\{\mathrm{C}_{2} \mathrm{C}_{6} \mathrm{H}_{5}\right\}$ $7.42\left(\mathrm{~d},{ }^{3} J_{\mathrm{H}, \mathrm{H}}=7 \mathrm{~Hz}, 8 \mathrm{H}, o-\mathrm{H}\right), 7.38-7.27(\mathrm{~m}, 12 \mathrm{H}, m-\mathrm{H}, p-\mathrm{H})$. Anal. Calcd for $\mathrm{Cu}_{6} \mathrm{C}_{106} \mathrm{H}_{82} \mathrm{~F}_{12} \mathrm{P}_{8}$ : C, 57.53; H, 3.74. Found: C, 57.43; $\mathrm{H}, 3.77$.

$\left[\mathrm{Cu}_{6}\left(\mathrm{C}_{2} \mathrm{C}_{6} \mathrm{H}_{4} \mathrm{Ph}\right)_{4}\left\{(\mathrm{PPh})_{3} \mathrm{CH}_{2}\right]\left(\mathrm{PF}_{6}\right)_{2}\right.$ (4). Yellow crystals (91\%). Single crystals of 4 suitable for XRD study were obtained by gasphase diffusion of pentane into its acetone solution at $+5{ }^{\circ} \mathrm{C}$ (acetonesolvated form). ESI MS $(\mathrm{m} / z):\left[\mathrm{Cu}_{3}\left(\mathrm{C}_{2} \mathrm{C}_{6} \mathrm{H}_{4} \mathrm{Ph}\right)_{2}\left\{\left(\mathrm{PPh}_{2}\right)_{3} \mathrm{CH}\right\}\right]^{+}$ 1113.10 (calcd 1113.09); [M] $]^{2+} 1113.10$ (calcd 1113.09); [M-C ${ }_{2} \mathrm{R}$ $\left.+2 \mathrm{HCO}_{2}\right]^{+} 2139.11$ (calcd 2139.11); $\left[\mathrm{M}+\mathrm{PF}_{6}\right]^{+} 2371.16$ (calcd $2371.15) .{ }^{31} \mathrm{P}\left\{{ }^{1} \mathrm{H}\right\}$ NMR $\left(\mathrm{CD}_{3} \mathrm{CN}, 298 \mathrm{~K}\right): \delta 6.8$ (s, $6 \mathrm{P}$, phosphine), -144.6 (sept, $\left.2 \mathrm{P}, \mathrm{PF}_{6}\right) .{ }^{1} \mathrm{H}$ NMR $\left(\mathrm{CD}_{3} \mathrm{CN}, 298 \mathrm{~K}\right): \delta\left\{\left(\mathrm{PPh}_{2}\right)_{3} \mathrm{CH}\right\}$ $7.79\left(\mathrm{~m}-\left(\mathrm{ABXX}^{\prime}\right),{ }^{3} J_{\mathrm{P}, \mathrm{H}}=12,{ }^{3} J_{\mathrm{H}, \mathrm{H}}=8 \mathrm{~Hz}, 24 \mathrm{H}, o-\mathrm{H}\right), 6.95\left(\mathrm{t},{ }^{3} J_{\mathrm{H}, \mathrm{H}}=\right.$ $7 \mathrm{~Hz}, 12 \mathrm{H}, p-\mathrm{H}), 6.77\left(\mathrm{dd},{ }^{3} J_{\mathrm{H}, \mathrm{H}}=8 \mathrm{~Hz},{ }^{3} J_{\mathrm{H}, \mathrm{H}}=7 \mathrm{~Hz}, 24 \mathrm{H}, m-\mathrm{H}\right)$, $6.06\left(\mathrm{q},{ }^{3} \mathrm{~J}_{\mathrm{P}, \mathrm{H}}=7 \mathrm{~Hz}, 2 \mathrm{H}, \mathrm{P}-\mathrm{CH}\right) ;\left\{\mathrm{C}_{2} \mathrm{C}_{6} \mathrm{H}_{4} \mathrm{Ph}\right\} 7.63\left(\mathrm{~d},{ }^{3} J_{\mathrm{H}, \mathrm{H}}=8 \mathrm{~Hz}\right.$, $\left.16 \mathrm{H}, o-\mathrm{H} \mathrm{C}_{6} \mathrm{H}_{4}, o-\mathrm{H} \mathrm{Ph}\right), 7.50\left(\mathrm{~d},{ }^{3} J_{\mathrm{H}, \mathrm{H}}=8 \mathrm{~Hz}, 8 \mathrm{H}, m-\mathrm{H} \mathrm{C}_{6} \mathrm{H}_{4}\right), 7.46$ $\left(\mathrm{dd},{ }^{3} J_{\mathrm{H}, \mathrm{H}}=8 \mathrm{~Hz},{ }^{3} J_{\mathrm{H}, \mathrm{H}}=7 \mathrm{~Hz}, 8 \mathrm{H}, m-\mathrm{H} \mathrm{Ph}\right), 7.39\left(\mathrm{t},{ }^{3} J_{\mathrm{H}, \mathrm{H}}=7 \mathrm{~Hz}, 4\right.$ $\mathrm{H}, p-\mathrm{H} \mathrm{Ph}$ ). Anal. Calcd for $\mathrm{Cu}_{6} \mathrm{C}_{130} \mathrm{H}_{98} \mathrm{~F}_{12} \mathrm{P}_{8}: \mathrm{C}, 62.03 ; \mathrm{H}, 3.92$. Found: C, 61.72; H, 3.91.

$\left[\mathrm{Cu}_{6}\left(\mathrm{C}_{2} \mathrm{C}_{6} \mathrm{H}_{4} \mathrm{CF}_{3}\right)_{4}\left\{\left(\mathrm{PPh}_{2}\right)_{3} \mathrm{CH}_{2}\right]\left(\mathrm{PF}_{6}\right)_{2}\right.$ (5). Yellow crystals (93\%). Single crystals of $\mathbf{5}$ suitable for XRD study were obtained by gas-phase diffusion of pentane into its acetone solution at $+5{ }^{\circ} \mathrm{C}$ (acetonesolvated form). ESI MS $(m / z):\left[\mathrm{Cu}_{3}\left(\mathrm{C}_{2} \mathrm{C}_{6} \mathrm{H}_{4} \mathrm{CF}_{3}\right)_{2}\left\{\left(\mathrm{PPh}_{2}\right)_{3} \mathrm{CH}\right\}\right]^{+}$ 1097.01 (calcd 1097.00); [M] $]^{2+} 1097.01$ (calcd 1097.00); $[\mathrm{M}+$ $\left.\mathrm{HCO}_{2}\right]^{+} 2239.02$ (calcd 2239.01); $\left[\mathrm{M}+\mathrm{PF}_{6}\right]^{+} 2338.99$ (calcd 2338.98). ${ }^{31} \mathrm{P}\left\{{ }^{1} \mathrm{H}\right\}$ NMR $\left(\mathrm{CD}_{2} \mathrm{Cl}_{2}, 298 \mathrm{~K}\right): \delta 10.3$ (s, $6 \mathrm{P}$, phosphine), -144.8 (sept, $\left.2 \mathrm{P}, \mathrm{PF}_{6}\right) .{ }^{1} \mathrm{H}$ NMR $\left(\mathrm{CD}_{2} \mathrm{Cl}_{2}, 298 \mathrm{~K}\right): \delta\left\{\left(\mathrm{PPh}_{2}\right)_{3} \mathrm{CH}\right\}$ $7.75\left(\mathrm{~m}-\left(\mathrm{ABXX}^{\prime}\right),{ }^{3} J_{\mathrm{P}, \mathrm{H}}=12,{ }^{3} J_{\mathrm{H}, \mathrm{H}}=8 \mathrm{~Hz}, 24 \mathrm{H}, o-\mathrm{H}\right), 7.01\left(\mathrm{t},{ }^{3} J_{\mathrm{H}, \mathrm{H}}=\right.$ $7 \mathrm{~Hz}, 12 \mathrm{H}, p-\mathrm{H}), 6.79\left(\mathrm{dd},{ }^{3} J_{\mathrm{H}, \mathrm{H}}=8 \mathrm{~Hz},{ }^{3} J_{\mathrm{H}, \mathrm{H}}=7 \mathrm{~Hz}, 24 \mathrm{H}, m-\mathrm{H}\right)$, $6.23\left(\mathrm{q},{ }^{3} \mathrm{~J}_{\mathrm{P}, \mathrm{H}}=7 \mathrm{~Hz}, 2 \mathrm{H}, \mathrm{P}-\mathrm{CH}\right) ;\left\{\mathrm{C}_{2} \mathrm{C}_{6} \mathrm{H}_{4} \mathrm{CF}_{3}\right\} 7.53\left(\mathrm{~d},{ }^{3} J_{\mathrm{H}, \mathrm{H}}=8 \mathrm{~Hz}\right.$, $8 \mathrm{H}, o-\mathrm{H}), 7.37\left(\mathrm{~d},{ }^{3} J_{\mathrm{H}, \mathrm{H}}=8 \mathrm{~Hz}, 8 \mathrm{H}, m-\mathrm{H}\right)$. Anal. Calcd for $\mathrm{Cu}_{6} \mathrm{C}_{110} \mathrm{H}_{78} \mathrm{~F}_{24} \mathrm{P}_{8}$ : C, 53.17; H, 3.16. Found: C, 53.34; $\mathrm{H}, 3.13$.

$\left[\mathrm{Cu}_{6}\left(\mathrm{C}_{2} \mathrm{C}_{5} \mathrm{H}_{4} \mathrm{~N}\right)_{4}\left\{\left(\mathrm{PPh}_{2}\right)_{3} \mathrm{CH}_{2}\right]\left(\mathrm{PF}_{6}\right)_{2}\right.$ (6). Green crystals (91\%). Single crystals of $\mathbf{6}$ suitable for XRD study were obtained by gas-phase diffusion of pentane into its dichloromethane solution at $+5{ }^{\circ} \mathrm{C}$ (dichloromethane-solvated form, 6A) and by gas-phase diffusion of diethyl ether into $\mathrm{MeCN}$ solution at $+5{ }^{\circ} \mathrm{C}$ (acetonitrile-solvated form, 6B). ESI MS $(m / z):\left[\mathrm{Cu}_{3}\left(\mathrm{C}_{2} \mathrm{C}_{5} \mathrm{H}_{4} \mathrm{~N}\right)_{2}\left\{\left(\mathrm{PPh}_{2}\right)_{3} \mathrm{CH}\right\}\right]^{+} 963.03$ (calcd $963.02) ; \quad[\mathrm{M}]^{2+} 963.03$ (calcd 963.02); $\left[\mathrm{Cu}_{2}\left(\mathrm{C}_{2} \mathrm{C}_{5} \mathrm{H}_{4} \mathrm{~N}\right)\right.$ ) $\left.\left\{\left(\mathrm{PPh}_{2}\right)_{3} \mathrm{CH}\right\}\right]^{+} 796.06(\mathrm{calcd} 796.06)$; $\left[\mathrm{Cu}_{4}\left(\mathrm{C}_{2} \mathrm{C}_{5} \mathrm{H}_{4} \mathrm{~N}\right)_{3}\left\{\left(\mathrm{PPh}_{2}\right)_{3} \mathrm{CH}\right\}\right]^{+} 1127.99$ (calcd 1127.98); $[\mathrm{M}+$ $\left.\mathrm{PF}_{6}\right]^{+} 2071.03($ calcd 2071.01$) .{ }^{31} \mathrm{P}\left\{{ }^{1} \mathrm{H}\right\}$ NMR $\left(\mathrm{CD}_{3} \mathrm{CN}, 298 \mathrm{~K}\right): \delta 2.7$ 
Scheme 1. Synthesis of Complexes 1-6 (Acetone, 298 K, 15 min, 91-95\% Yields)
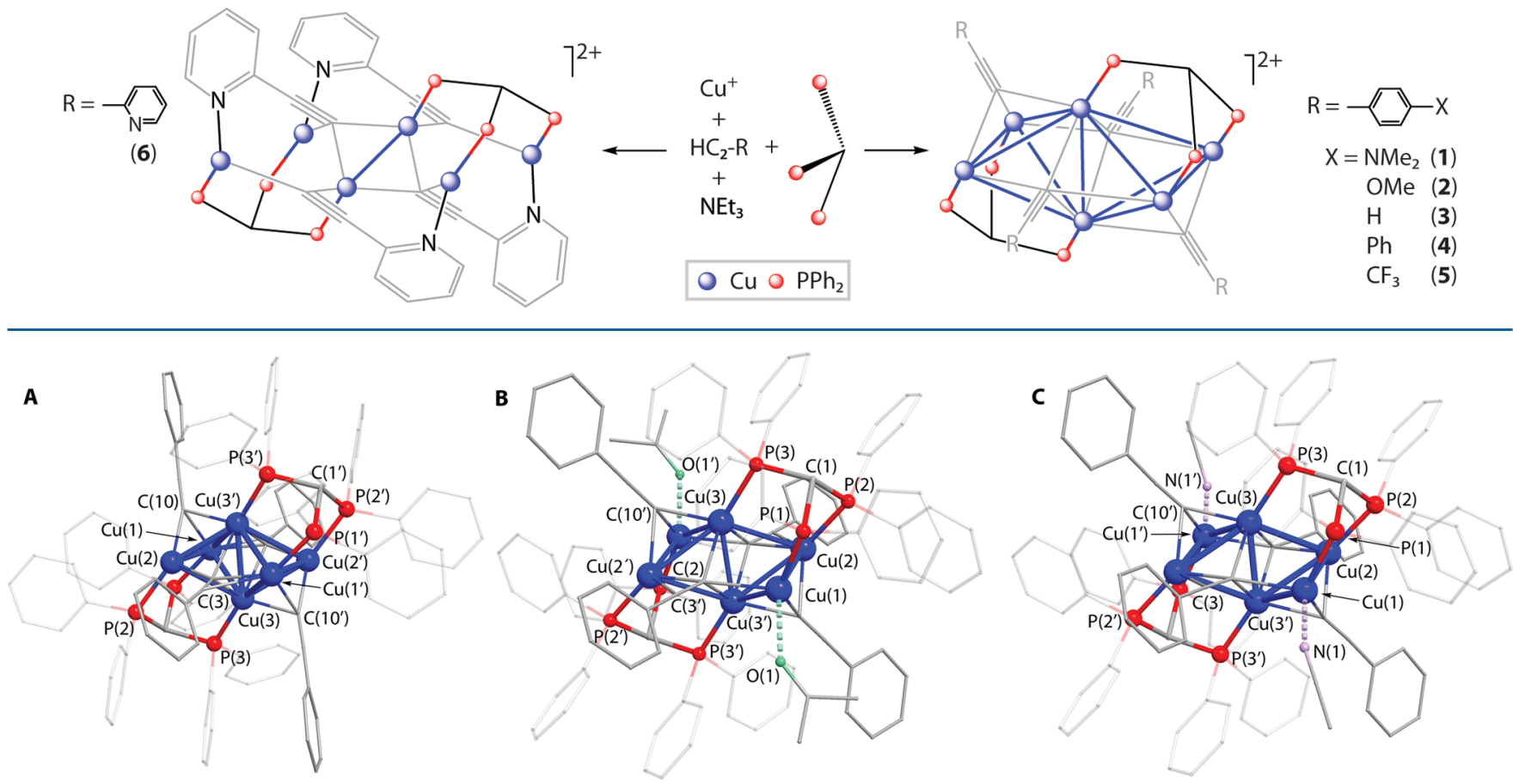

Figure 1. Molecular views of solvent-free (A), acetone (B), and acetonitrile (C, one of two independent molecules is shown) solvates of complex 3. Symmetry transformations to generate equivalent atoms (') in (A): 2-x, 2-y, 1-z; (B): 2-x, 2-y, 2-z; and (C): 1-x, 1-y, -z.

(br s, $6 \mathrm{P}$, phosphine), -144.6 (sept, $\left.2 \mathrm{P}, \mathrm{PF}_{6}\right) .{ }^{1} \mathrm{H}$ NMR $\left(\mathrm{CD}_{3} \mathrm{CN}\right.$, $298 \mathrm{~K}): \delta\left\{\left(\mathrm{PPh}_{2}\right)_{3} \mathrm{CH}\right\} 7.78($ br m, $24 \mathrm{H}, o-\mathrm{H}), 7.03(\mathrm{br} \mathrm{m}, 12 \mathrm{H}, p-$ $\mathrm{H}), 6.83$ (br m, $24 \mathrm{H}, m-\mathrm{H}), 5.49($ br m, $2 \mathrm{H}, \mathrm{P}-\mathrm{CH}) ;\left\{\mathrm{C}_{2} \mathrm{C}_{5} \mathrm{H}_{4} \mathrm{~N}\right\}$ 7.39-6.83 (set of multiplets, $16 \mathrm{H}, \mathrm{C}_{5} \mathrm{H}_{4} \mathrm{~N}$ ). Anal. Calcd for $\mathrm{C}_{102} \mathrm{H}_{78} \mathrm{Cu}_{6} \mathrm{~F}_{12} \mathrm{~N}_{4} \mathrm{P}_{8}$ : C, 55.26; H, 3.55; N, 2.53. Found: C, 55.15; H, 3.63; N, 2.39 .

Photophysical Measurements. The steady-state emission and excitation spectra of complexes 1-6 in solid state at room temperature and at $78 \mathrm{~K}$ were recorded on a FluoroLog 3 Horiba spectrofluorometer. The xenon lamp $(450 \mathrm{~W})$ was applied as a light source to obtain luminescence. A pulse laser DTL-399QT "Laser-export Co. Ltd." (maximum of emission at $351 \mathrm{~nm}, 50 \mathrm{~mW}$, pulse width of $6 \mathrm{~ns}$, repetition rate of $1 \mathrm{kHz}$ ), a digital oscilloscope Tektronix DPO3034 (bandwidth $300 \mathrm{MHz}$ ), a MUM monochromator (LOMO, interval of wavelengths of $10 \mathrm{~nm}$ ), and a Hamamatsu photomultiplier tube were used for lifetime measurements. Absolute emission quantum yield was determined using a Quanta-phi integration sphere.

$X$-ray Structure Determinations. The crystals of 2-6 were immersed in cryo-oil, mounted in a Nylon loop, and measured at a temperature of $120 \mathrm{~K}$. The X-ray diffraction data were collected on a Bruker Kappa APEX II Duo diffractometer using Mo K $\alpha$ radiation $(\lambda$ $=0.71073 \AA)$. The APEX $2^{12}$ program package was used for cell refinements and data reductions. The structures were solved by direct methods using the SHELXS-2013 ${ }^{13}$ program with the WinGX ${ }^{14}$ graphical user interface. A semiempirical absorption correction $(S A D A B S)^{15}$ was applied to all data. Structural refinements were carried out using SHELXL-2013. ${ }^{13}$ The crystals 3A and 3C were measured on an Agilent Technologies Supernova Atlas diffractometer at a temperature of $100 \mathrm{~K}$ using monochromated microfocused $\mathrm{Cu} \mathrm{K} \alpha$ radiation $(\lambda=1.54184 \AA)$. The CrysAlisPro ${ }^{16}$ program package was used for cell refinements and data reductions. The structures were solved by direct methods and refined using the SHELXS-2013 $3^{13}$ programs incorporated in the OLEX2 ${ }^{17}$ program package. Empirical absorption correction for $3 \mathrm{~A}$ and $3 \mathrm{C}$ was applied in the CrysAlisPro ${ }^{16}$ program complex using spherical harmonics and implemented in the SCALE3 ABSPACK scaling algorithm. Some of the missing solvent molecules in the crystals of $\mathbf{2}$ and $\mathbf{3}$ were omitted as they were disordered and could not be resolved unambiguously. The missing solvent was taken into account by using a SQUEEZE routine of PLATON. ${ }^{18}$ The contribution of the solvent to the cell content was not taken into account. High values of the refinement parameters and overall quality of the data in the structure of $3 \mathrm{C}$ are due to the low quality of the crystals and its very low diffraction ability. The ADPs for most atoms were defined and kept fixed during the refinement. However, the positions of atoms were localized objectively and were refined without any restrictions so that the structural model of $3 \mathrm{C}$ is highly convincing. In 5 , the acetone crystallization molecule was disordered over two sites and refined with the occupancies $0.87 / 0.13$. The acetone molecules in $\mathbf{4}$ were partially lost and were therefore refined with an occupation factor of 0.5 . The displacement parameters of all the atoms in this moiety were restrained so that their $U_{i j}$ components approximate to isotropic behavior. In 2 , a disorder model involving two alkynyl ligands (C2-C10, O1 and C12-C19, O2 together with the dichloromethane crystallization solvent molecule C113, Cl6, Cl7) was built, and the components were refined with occupancies of $0.51 / 0.49$ and $0.70 / 0.30$, respectively. One component of the aromatic ring (C13A-C18A) was geometrically idealized. Geometrical and displacement restraints and constraints were applied to the solvent molecule. Some of the $\mathrm{PF}_{6}{ }^{-}$counterions in 5 were disordered over two positions each and were refined with occupancies of $0.73 / 0.27$. A series of geometrical and displacement constraints and restraints were applied to these moieties. The $\mathrm{CF}_{3}$ group of an alkynyl ligand $(\mathrm{F} 1-\mathrm{F} 3)$ in $\mathbf{5}$ was modeled to occupy two positions with factors of $0.28 / 0.72$, the displacement parameters of the fluorine atoms were restrained to approximate isotropic behavior. One of the triphosphine phenyl rings (C24-C29) was disordered over two sites and was refined with occupancies of $0.52 / 0.48$. Both components of the disorder model were geometrically idealized.

The carbon-bound $\mathrm{H}$ atoms were placed in calculated positions and were included in the refinement in the "riding" model approximation with $\mathrm{U}_{\text {iso }}(\mathrm{H})$ set to $1.5 \mathrm{U}_{\text {eq }}(\mathrm{C})$ and $\mathrm{C}-\mathrm{H} 0.96 \AA$ for $\mathrm{CH}_{3}$ groups, $\mathrm{U}_{\text {iso }}(\mathrm{H})$ set to $1.2 \mathrm{U}_{\text {eq }}(\mathrm{C})$ and $\mathrm{C}-\mathrm{H} 0.97 \AA$ for $\mathrm{CH}_{2}$ groups, $\mathrm{U}_{\text {iso }}(\mathrm{H})$ set to $1.2 \mathrm{U}_{\text {eq }}(\mathrm{C})$ and $\mathrm{C}-\mathrm{H} 0.93 \AA$ for the $\mathrm{CH}$ groups, and $\mathrm{U}_{\text {iso }}(\mathrm{H})$ set to $1.2 \mathrm{U}_{\mathrm{eq}}(\mathrm{C})$ and $\mathrm{C}-\mathrm{H} 0.98 \AA$ for the tertiary $\mathrm{CH}$ groups. The crystallographic details are summarized in Supporting Information Table S1. 
Computational Details. The DFT codes implemented in Gaussian $09^{19}$ were applied in the computational part of this study. Hybrid exchange-correlation $\mathrm{PBEO}^{20}$ functional was used together with all-electrons basis set of triple-valence-zeta with the polarization function (def2-TZVP) for the copper atoms, ${ }^{21}$ split-valence (SV) basis sets $^{22}$ for the rest of the non-hydrogen elements, and 6-31G(d) for hydrogen atoms. Initial geometries for all complexes were taken from XRD data obtained in this work. The time-dependent (TD)-DFT method was used to optimize the singlet ground state (SGS) and find distortions of these structures in the triplet excited states (TES), ${ }^{23}$ which are responsible for luminescence. Spectral features and electronic properties were processed and plotted by GaussSum code. ${ }^{24}$

\section{RESULTS AND DISCUSSION}

Synthesis and Structural Characterization. Preparation of the title compounds is based on the reaction of a labile acetonitrile $\mathrm{Cu}^{\mathrm{I}}$ complex with templating triphosphine (tppm) ligand followed by the addition of the corresponding alkyne and deprotonating agent (triethylamine). The effective selfassembly of the clusters having a general formula $\left[\mathrm{Cu}_{6}\left(\mathrm{C}_{2}-4-\right.\right.$ $\left.\left.\mathrm{C}_{6} \mathrm{H}_{4}-\mathrm{X}\right)_{4}\left\{\left(\mathrm{PPh}_{2}\right)_{3} \mathrm{CH}\right\}_{2}\right]^{2+}\left(\mathrm{X}=\mathrm{NMe}_{2}(1), \mathrm{OMe}(2), \mathrm{H}(3)\right.$, $\left.\mathrm{Ph}(4), \mathrm{CF}_{3}(5)\right)$ proceeds within a few minutes to give final products in nearly quantitative yields $(91-95 \%$ after recrystallization, Scheme 1).

The structures of complexes 2-6 in the solid state were determined by X-ray diffraction studies (Figures 1 and 2 and



Figure 2. Molecular view of complex 6B. Symmetry transformations to generate equivalent atoms $\left({ }^{\prime}\right)$ in $6: 2-x,-y, 2-z$.

Figure S1, the ORTEP $^{25}$ views are also shown in Figure S2). The selected structural parameters are listed in Table 1 and Table S2. Dicationic clusters $\mathbf{2}-\mathbf{5}$ consist of a distorted octahedral metal core stabilized by the bridging ligands. The triphosphines and two alkynyl groups are coordinated in $\mu^{3}$ mode to occupy four octahedron faces. Two other $-\mathrm{C} \equiv \mathrm{CR}$ ligands are $\mu^{4}$-bound to the metal framework through additional $\eta^{2}$-coordination of the $\mathrm{C} \equiv \mathrm{C} \pi$-systems to an adjacent copper ion. All $\mathrm{Cu}-\mathrm{Cu}$ distances in $\mathbf{2 - 5}$ fall in the 2.52-2.85 $\AA$ range that is lower than or comparable to the sum of two $\mathrm{Cu}$ van der Waals radii $(2.80 \AA)$, which is indicative of efficient metallophilic interactions and is similar to the intermetallic separations found in the previously reported $\mathrm{Cu}^{\mathrm{I}}$ clusters. $^{9-11}$

Crystallization of complexes $2-5$ from acetonitrile $(2,3)$ or acetone (3-5) solutions results in the formation of solvates via the coordination of two solvent molecules to copper ions of the cluster core (Figure 1 and Figure S1). The general structural motif of the solvated complexes remains unchanged to maintain the pseudo octahedral structure of the cluster core and coordination modes of the phosphine and alkynyl ligands. The bond lengths between copper ions and the atoms of coordinated alkyne and phosphine ligands in $\mathbf{2}$ and $\mathbf{3}$ undergo rather small variations, and the major changes occur within the cluster core. All but two $\mathrm{Cu}-\mathrm{Cu}$ distances in the cluster core remain nearly unchanged (vary within $0.1 \AA$ ) compared to the copper-copper contacts in the parent solvent-free complexes. The most important changes are observed for the $\mathrm{Cu}-\mathrm{Cu}$ bonds $(\mathrm{Cu}(1)-\mathrm{Cu}(2)$ and $\mathrm{Cu}(1)-\mathrm{Cu}(3))$, which involve copper ions $\mathrm{Cu}(1)$ bound to the solvent molecules. Upon coordination of the crystallization solvent, the $\mathrm{Cu}(1)-\mathrm{Cu}(2)$ separations get slightly elongated from $2.5843 \AA$ in $3 \mathrm{~A}$ to 2.6425 and $2.6708 \AA$ in acetone $3 \mathrm{~B}$ and acetonitrile 3C solvates, respectively (a similar trend is observed for complex 2, see Tables S2). More dramatic changes are seen for $\mathrm{Cu}(1)-$ $\mathrm{Cu}(3) / \mathrm{Cu}\left(3^{\prime}\right)$ distances corresponding to tppm-bridged and nonbridged metal-metal bonds, which demonstrate very close values in nonsolvated species (2.7665 and $2.7368 \AA$, respectively). However, binding the additional ligand (acetone or acetonitrile) to $\mathrm{Cu}(1)$ leads to significant elongation of the triphosphine-bridged contact to 3.0597 and $3.081 \AA$ in 3B and 3C complexes, respectively, that eventually results in a loss of metallophilic interactions. Conversely, the nonbridged $\mathrm{Cu}(1)-$ $\mathrm{Cu}(3) / \mathrm{Cu}\left(3^{\prime}\right)$ contact gets shorter with solvation of the cluster molecules (from $2.7368 \AA$ in $3 \mathrm{~A}$ to 2.6504 in 3C, see the similar trend for 2 in Table S2). It is also worth noting that coordination of the solvent molecules in $\mathbf{1 - 5}$ is quite weak, and the solvent-free forms can be easily obtained from the solvates upon thoroughly drying the samples under vacuum, which was confirmed by elemental analysis.

The structural motif of $\mathbf{6}$ is significantly different from those found for complexes 1-5 (Figure 2). Complex 6 was found to crystallize in two forms depending on the solvents: $6 \mathbf{A}\left(P 2_{1} / c\right.$ space group, contains dichloromethane crystallization solvent, easily converted into a solvent-free form) and $6 \mathrm{~B}(P \overline{1}$ space group, acetonitrile crystallization adduct). The metal skeleton of this cluster in both forms consists of six copper atoms, and its ligand environment contains two $\mu^{3}$ coordinated triphosphines and four alkynyl ligands of two types. Each of the phosphines bridges three copper atoms, which do not form closed triangles, however, in contrast to complexes 2-5. The presence of 2-pyridyl substituents in the alkynyl ligands substantially changes their coordination modes through additional bonding of pyridyl $\mathrm{N}$ atoms to the cluster framework. To fit into this bonding network the cluster core forms an open structure with only one effective metal-metal bond $\left(\mathrm{Cu}(3)-\mathrm{Cu}\left(3^{\prime}\right) 2.6057(7) \AA \AA\right.$ and 2.6028(9) $\AA$ in $6 \mathrm{~A}$ and $6 \mathrm{~B}$, respectively). The rest of the $\mathrm{Cu}-\mathrm{Cu}$ distances exceed 2.85 $\AA$, indicating weaker metal-metal interactions (see selected interatomic distances in Table S3). From the viewpoint of bond energy, the formation of copper-pyridyl bonds presumably compensates the loss of metallophilic contacts in the cluster skeleton.

Because of coordination of 2-ethynylpyridine ligands via $\mathrm{C}$ and $\mathrm{N}$ atoms to the copper cluster core, no other vacancies are available in 6 for additional interaction with, e.g., solvent molecules; therefore, no solvates of 6 were obtained.

Mass Spectrometry and NMR Spectroscopic Study. The ESI mass spectra of 1-6 display the major signals of 
Table 1. Selected Bond Lengths (§) for Complex 3 and Its Solvated Forms

\begin{tabular}{|c|c|c|c|}
\hline & solvent free, $\mathbf{A}$ & acetone solvate, $\mathbf{B}$ & acetonitrile solvate, $\mathrm{C}$ \\
\hline $\mathrm{Cu}(1)-\mathrm{Cu}(2)$ & $2.5843(7)$ & $2.6425(5)$ & $2.6708(5)$ \\
\hline $\mathrm{Cu}(1)-\mathrm{Cu}(3)$ & $2.7665(6)$ & $3.0597(6)$ & $3.0809(5)$ \\
\hline $\mathrm{Cu}(1)-\mathrm{Cu}\left(3^{\prime}\right)$ & $2.7368(6)$ & $2.7126(6)$ & $2.6504(4)$ \\
\hline $\mathrm{Cu}(2)-\mathrm{Cu}(3)$ & $2.7116(7)$ & $2.7182(5)$ & $2.7116(4)$ \\
\hline $\mathrm{Cu}(2)-\mathrm{Cu}\left(3^{\prime}\right)$ & $2.5720(6)$ & $2.6939(5)$ & $2.6884(4)$ \\
\hline $\mathrm{Cu}(3)-\mathrm{Cu}\left(3^{\prime}\right)$ & $2.5826(7)$ & $2.5500(7)$ & $2.5106(6)$ \\
\hline $\mathrm{Cu}(1)-\mathrm{O}(1) / \mathrm{N}(1)$ & & $2.410(5)$ & $2.089(3)$ \\
\hline $\mathrm{Cu}(1)-\mathrm{C}\left(2 / 2^{\prime}\right)$ & $2.068(3)$ & $2.258(3)$ & $2.224(2)$ \\
\hline $\mathrm{Cu}(1)-\mathrm{C}(10)$ & $2.195(3)$ & $2.033(3)$ & $2.027(3)$ \\
\hline $\mathrm{Cu}(2)-\mathrm{C}\left(2^{\prime} / 2\right)$ & $2.071(3)$ & $2.092(3)$ & $2.099(2)$ \\
\hline $\mathrm{Cu}(2)-\mathrm{C}(10)$ & $1.977(3)$ & $2.120(3)$ & $2.093(2)$ \\
\hline $\mathrm{Cu}(2)-\mathrm{C}(3)$ & $2.947(3)$ & $2.412(3)$ & $2.409(3)$ \\
\hline $\mathrm{Cu}(3)-\mathrm{C}(2)$ & $2.127(3)$ & $2.184(3)$ & $2.192(3)$ \\
\hline $\mathrm{Cu}\left(3^{\prime}\right)-\mathrm{C}(2)$ & $2.347(4)$ & $2.196(3)$ & $2.162(2)$ \\
\hline $\mathrm{Cu}\left(3^{\prime}\right)-\mathrm{C}(10)$ & $2.155(3)$ & $2.152(3)$ & $2.177(2)$ \\
\hline $\mathrm{Cu}(1)-\mathrm{P}(1)$ & $2.2235(8)$ & $2.2834(8)$ & $2.2807(7)$ \\
\hline $\mathrm{Cu}(2)-\mathrm{P}(2)$ & $2.2413(8)$ & $2.2276(8)$ & $2.2156(6)$ \\
\hline $\mathrm{Cu}(3)-\mathrm{P}(3)$ & $2.2624(8)$ & $2.2605(8)$ & $2.2659(7)$ \\
\hline
\end{tabular}

$\left[\mathrm{Cu}_{3}\left(\mathrm{C}_{2} \mathrm{R}\right)_{2}\left\{\left(\mathrm{PPh}_{2}\right)_{3} \mathrm{CH}\right\}\right]^{+}\left(\mathrm{R}=4-\mathrm{X}-\mathrm{C}_{6} \mathrm{H}_{4}(\mathbf{1}-\mathbf{5})\right.$ and $\mathrm{C}_{5} \mathrm{H}_{4} \mathrm{~N}$ (6); $\mathrm{X}=\mathrm{NMe}_{2}$ (1), $\left.\mathrm{OMe}(2), \mathrm{H}(3), \mathrm{Ph}(4), \mathrm{CF}_{3}(5)\right)$ cations that correspond to half of the molecular ions of the title compounds. The signals of doubly charged cations $[\mathrm{M}]^{2+}$ are also observed in ESI-MS with the $\mathrm{m} / z$ values and isotopic patterns being in complete agreement with the calculated ones for $\left[\mathrm{Cu}_{6}\left(\mathrm{C}_{2} \mathrm{R}\right)_{4}\left\{\left(\mathrm{PPh}_{2}\right)_{3} \mathrm{CH}\right\}_{2}\right]^{2+}\left(\mathrm{R}=4-\mathrm{X}-\mathrm{C}_{6} \mathrm{H}_{4}(1-5)\right.$ and $\left.\mathrm{C}_{5} \mathrm{H}_{4} \mathrm{~N}(6)\right)$ molecular ions, as well as the signals of $[\mathrm{M}+$ $\left.\mathrm{PF}_{6}\right]^{+}$and $\left[\mathrm{M}+\mathrm{HCO}_{2}\right]^{+}$ions.

The ${ }^{31} \mathrm{P}$ NMR spectra of $\mathbf{1 - 6}$ at $298 \mathrm{~K}$ consist of sharp (15 ) and broad (6) singlet resonances in the region of 5.9-10.3 ppm, which correspond to the $\mathrm{P}$ atoms of the thiphosphine ligand, and a septuplet at -144.6 (in $\mathrm{CD}_{3} \mathrm{CN}$ solution) or -144.8 (in $\mathrm{CD}_{2} \mathrm{Cl}_{2}$ solution) of the $\mathrm{PF}_{6}^{-}$counterion. The presence of only one signal from tppm can be a result of fast intramolecular dynamics that is most likely determined by the exchange of alkynyl ligands, which includes concerted $\left\{\mu^{3}: \eta^{2} \leftrightarrow\right.$ $\left.\mu^{3}\right\}$ pairwise transformation of the ligand coordination mode. This nonrigidity of coordination environment in solution leads to increased molecular symmetry and makes all the phosphorus atoms equivalent. The presence of a fluxional process of this sort is clearly demonstrated by the VT ${ }^{31} \mathrm{P}$ NMR spectra of complexes 3 and 6 . For cluster 3 , the sharp singlet at $6.7 \mathrm{ppm}$ $(298 \mathrm{~K})$ splits into two broadened multiplets at $193 \mathrm{~K}$ with a 1:2 integral intensity ratio (Figure 3 ) that fits well the symmetry of the structural pattern revealed in the solid state. In the case of complex 6 , the structure found in the solid-state is additionally stabilized by coordination of the pyridyl substituents of alkynyl ligands that slows down the dynamics and results in the detection of a broadened, featureless structural pattern at $298 \mathrm{~K}$ (Figure 4). However, this signal is transformed into a singlet at $2.7 \mathrm{ppm}$ upon warming of the $\mathrm{MeCN}$ solution up to $323 \mathrm{~K}$. Conversely, the ${ }^{31} \mathrm{P}$ NMR spectrum of 6 at $233 \mathrm{~K}$ displays three complicated multiplets with equal integral intensities that is in complete agreement with the symmetry of the rigid solid-state structure of this complex.

In turn, the ${ }^{1} \mathrm{H}$ NMR data for $\mathbf{1 - 6}$ are also compatible with the structure/dynamics hypothesis described above. For example, the proton spectrum of $\mathbf{1}$ at $298 \mathrm{~K}$ (a high temperature limit for this complex, see Figure 5) in the low-

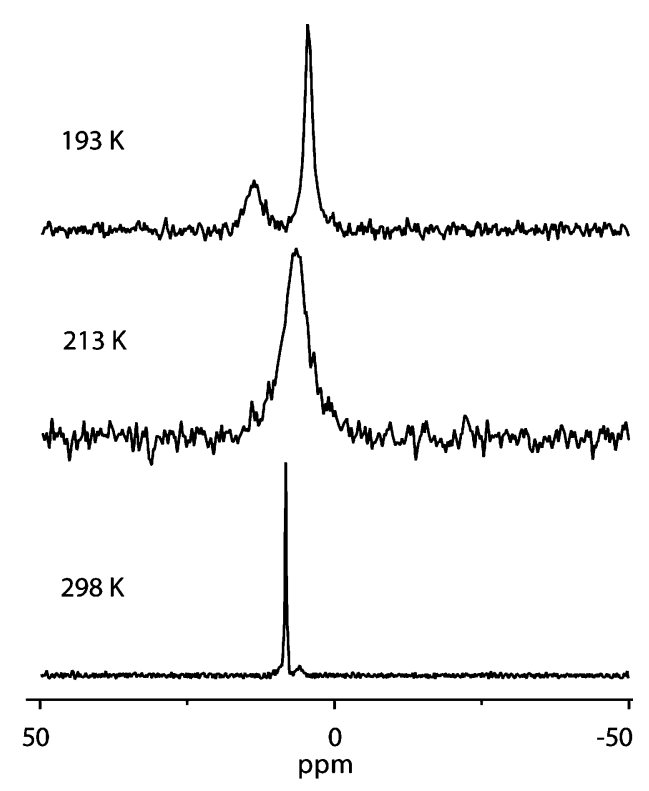

Figure 3. ${ }^{31} \mathrm{P}\left\{{ }^{1} \mathrm{H}\right\}$ VT NMR spectra of 3 in $\mathrm{CD}_{3} \mathrm{CN}$.

field area displays a set of multiplets corresponding to the ortho-, para-, and meta-protons $(7.78,6.93$, and $6.74 \mathrm{ppm}$, respectively) of the tppm phenyl rings together with the resonance of methine proton $(6.01 \mathrm{ppm})$ and doublets of ortho- and meta-protons (7.25 and $6.60 \mathrm{ppm}$, respectively) of the phenylene spacer of alkynyl ligands. In the high-field area of this spectrum, the signal of methyl protons $(2.91 \mathrm{ppm})$ of the $\mathrm{NMe}_{2}$ group is found. These observations are in agreement with the structural pattern shown in Scheme 1 and are indicative of the structure symmetrization due to the dynamics suggested above. Similar ${ }^{1} \mathrm{H}$ NMR spectra were observed for complexes 2-6 at a high temperature limit (298 K). In summary, the spectroscopic data obtained show that the structural patterns found in the solid state for 1-6 remain unchanged in solution along with the presence of intramolecular dynamics, which can be frozen at low temperature.

Photophysical Properties. The photophysical data for clusters $\mathbf{1 - 6}$ are given in Table 2. The solid state emission spectra are shown in Figures 6 and 7. 

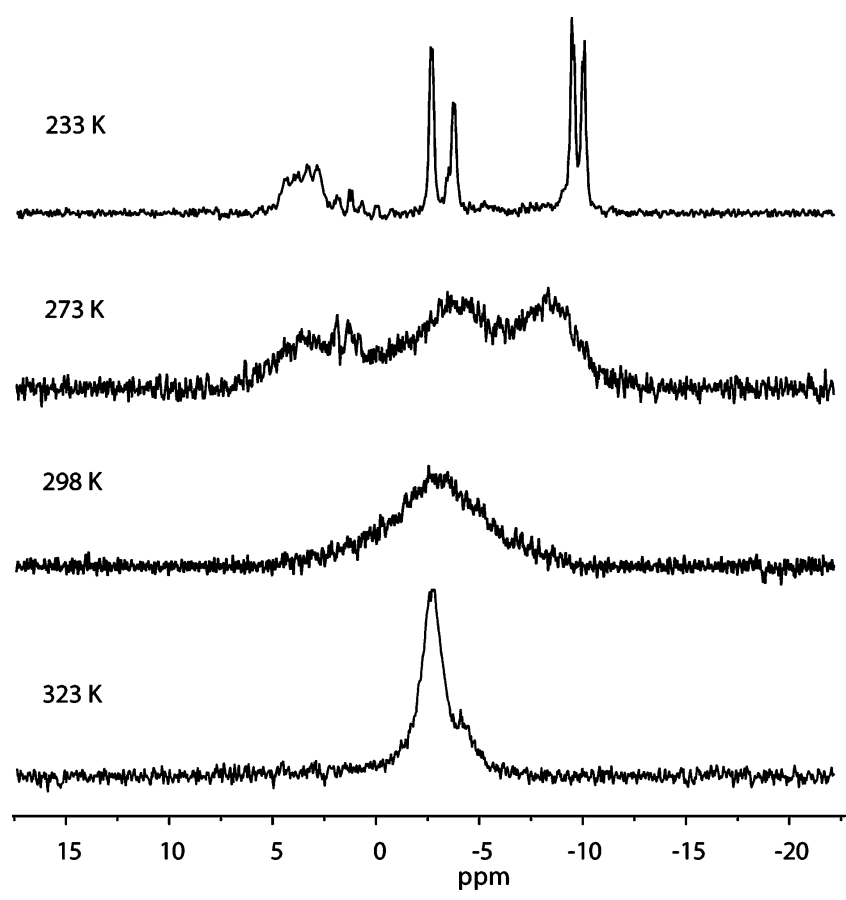

Figure 4. ${ }^{31} \mathrm{P}\left\{{ }^{1} \mathrm{H}\right\}$ VT NMR spectra of 6 in $\mathrm{CD}_{3} \mathrm{CN}$.

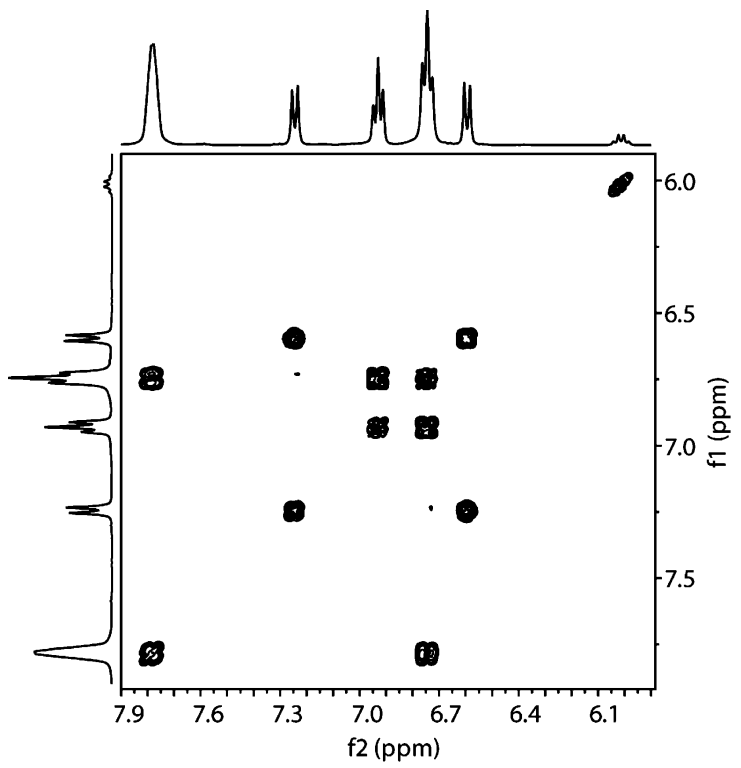

Figure 5. ${ }^{1} \mathrm{H}-{ }^{1} \mathrm{H}$ COSY NMR spectrum of $\mathbf{1}$ (low field area, $\mathrm{CD}_{3} \mathrm{CN}$, $298 \mathrm{~K})$.

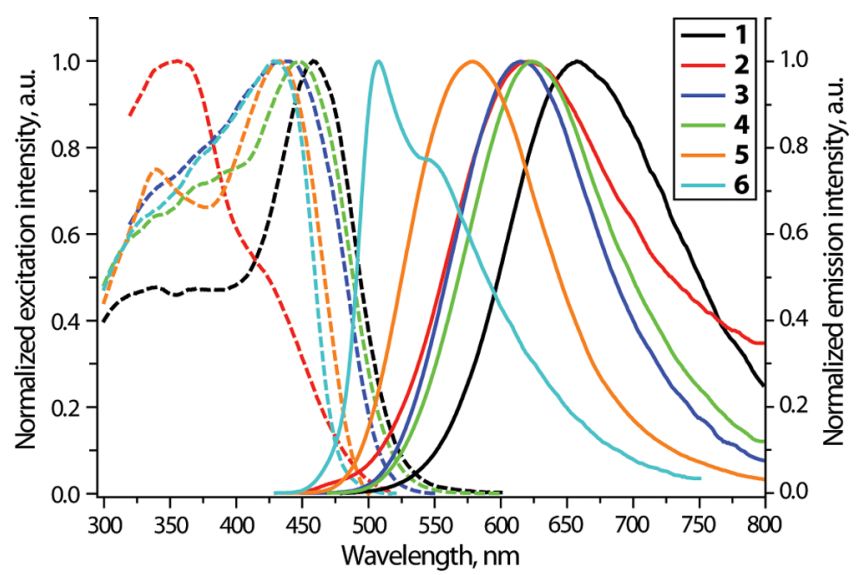

Figure 6. Normalized excitation (dashed lines) and emission (solid lines) spectra of solvent-free complexes 1-6 at $298 \mathrm{~K}$ in the solid state (excitation spectra were measured at the maximum of the corresponding emission band; emission was excited at $410 \mathrm{~nm}$ for 1-5 and $380 \mathrm{~nm}$ for 6).

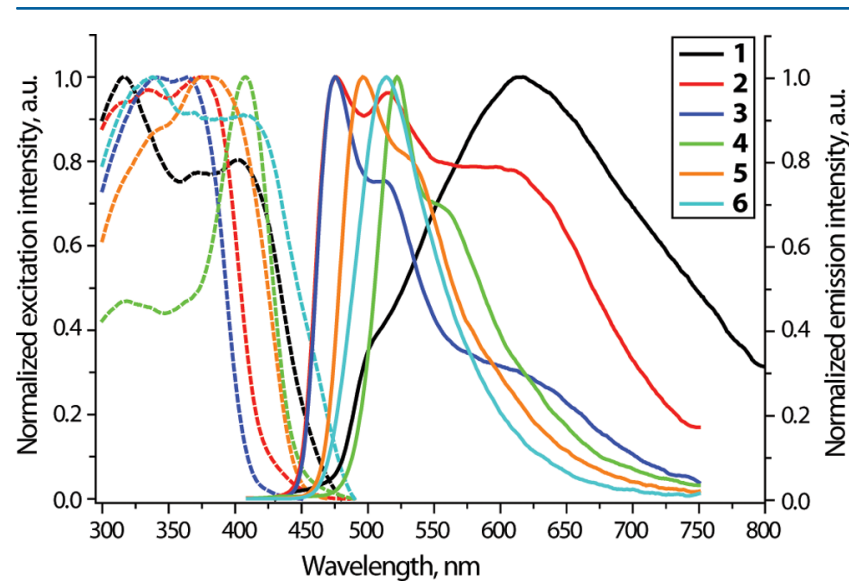

Figure 7. Normalized excitation (dashed lines) and emission (solid lines) spectra of acetonitrile-saturated complexes 1-6 at $298 \mathrm{~K}$ in the solid state (excitation spectra were measured at the maximum of the corresponding emission band; emission was excited at $380 \mathrm{~nm}$ for 2-6 and $410 \mathrm{~nm}$ for $\mathbf{1}$ ).

Excitation spectra of complexes $\mathbf{1 - 6}$ in the solid state at 298 $\mathrm{K}$ display high and low energy components, located at approximately 350 and $430 \mathrm{~nm}$, respectively, in which the former dominates for compound 2, whereas it appears as a weaker band/shoulder for complexes 1 and 3-6. Both components may be tentatively ascribed to a mixture of metal-perturbed intraligand $\pi-\pi^{*}$ (alkynyl moiety) and MLCT $\left[\mathrm{d}(\mathrm{Cu})-\pi^{*}\right.$ (acetylide/phosphine $\left.)\right]$ transitions analogous to the polynuclear copper alkynyl phosphine complexes studied

Table 2. Photophysical Properties of $1-6$ in the Solid State at $298 \mathrm{~K}^{a}$

\begin{tabular}{|c|c|c|c|c|c|c|c|c|}
\hline complex & $\lambda(\mathrm{sf})_{\mathrm{em}}, \mathrm{nm}$ & $\lambda(\mathrm{as})_{\mathrm{em}}, \mathrm{nm}$ & $\lambda(\mathrm{sf})_{\mathrm{ex}} \mathrm{nm}$ & $\lambda(\text { as })_{\mathrm{ex}}, \mathrm{nm}$ & QY(sf), \% & QY(as), \% & $\tau(\mathrm{sf}), \mu \mathrm{s}$ & $\tau(\mathrm{as}), \mu \mathrm{s}$ \\
\hline 1 & 658 & $505(\mathrm{sh}) ; 617$ & $352 ; 458$ & $316 ; 402$ & 1.5 & 0.1 & $0.7(45 \%) ; 0.24(55 \%)$ & $0.7(20 \%) ; 0.24(80 \%)$ \\
\hline 2 & 621 & $476 ; 514 ; 596(\mathrm{sh})$ & $355 ; 418(\mathrm{sh})$ & $335 ; 375$ & 4.1 & 7.0 & $7(25 \%) ; 1.9(75 \%)$ & $18(45 \%) ; 3.0(55 \%)$ \\
\hline 3 & 615 & $475 ; 513 ; 612(\mathrm{sh})$ & $360(\mathrm{sh}) ; 435$ & $341 ; 364$ & 16.5 & 8.7 & $17(60 \%) ; 3.2(40 \%)$ & $60(70 \%) ; 4.2(30 \%)$ \\
\hline 4 & 624 & $522 ; 554(\mathrm{sh})$ & $371(\mathrm{sh}) ; 447$ & $318 ; 408$ & 7.5 & 0.3 & $18(30 \%) ; 2.0(70 \%)$ & $1.8(5 \%) ; 0.21(95 \%)$ \\
\hline 5 & 579 & $496 ; 528(\mathrm{sh})$ & $340 ; 433$ & $344(\mathrm{sh}) 381$ & 11.7 & 3.3 & $29(55 \%) ; 4.1(45 \%)$ & $30(35 \%) ; 9(65 \%)$ \\
\hline 6 & $508 ; 546(\mathrm{sh})$ & 514 & $365(\mathrm{sh}) ; 428$ & $338 ; 406$ & 3.7 & 4.1 & $11(35 \%) ; 1.3(65 \%)$ & $19(65 \%) ; 4.0(35 \%)$ \\
\hline
\end{tabular}

${ }^{a}$ Solvent-free (sf) complexes: $\lambda_{\mathrm{ex}}=410 \mathrm{~nm}$ for $\mathbf{1}-\mathbf{5}$ and $380 \mathrm{~nm}$ for $\mathbf{6}$. Acetonitrile solvates (as): $\lambda_{\mathrm{ex}}=380 \mathrm{~nm}$ for $2-6$ and $410 \mathrm{~nm}$ for $\mathbf{1}$. Average uncertainties in the lifetime measurements are $10 \%$ for time scale and $5 \%$ for the contribution of the corresponding decay given in parentheses. 
earlier. ${ }^{9-11}$ It is worth noting that charge transfer processes are probably better described as MMLCT ones because of strong copper-copper bonding inside the cluster core.

All substances under study luminesce in the solid state with emission band maxima varying from $658 \mathrm{~nm}$ for cluster 1 to $508 \mathrm{~nm}$ in the case of 6 . The title compounds display moderate to weak emission with quantum yields from $1.5 \%$ (1) to $16.5 \%$ (3). The excited state lifetimes of 1-6 fall in the range of 0.24$29 \mu \mathrm{s}$. This observation, together with the large values of Stokes shift, indicates that the luminescence originates from the triplet manifold, i.e., phosphorescence.

A double exponential fit was applied to the luminescence decays of all the studied compounds. This approach is often used to treat the solid state emission, ${ }^{26}$ which may arise from the electronic transitions of a similar origin but show some variation in the lifetimes due to, e.g., the local differences in molecular arrangement in the crystal cell. The structural inequivalence of chemically identical chromophore centers as a result of crystal packing is quite common and can be illustrated, e.g., by complexes $\mathbf{2 A}$ and $\mathbf{2 B}$, each of which has two independent molecules in the unit cell.

The exposure of $\mathbf{1 - 5}$ to vapors of acetonitrile leads to substantial changes in their luminescence behavior, which is evidently related to coordination of $\mathrm{CH}_{3} \mathrm{CN}$ molecules that was clearly demonstrated by the XRD studies of the crystals obtained from acetonitrile or acetone-containing solutions. It has to be noted that photophysical characteristics of the crystalline solvated samples and those obtained by saturation of the solvent-free solids with the corresponding solvent vapors are identical (see for example, Figure S4). This allows for speculation on the nature of chromophores based on the solidstate structures of solvated complexes, which are equally applicable to the solvates and samples obtained upon solvent vapor saturation.

One of the clear consequences of solvent coordination are drastic structural changes (e.g., $\mathrm{Cu}-\mathrm{Cu}$ distances, vide supra) inside the metal core, which give rise to substantial variations in the energy of the orbitals involved in the emission and, consequently, of its characteristics. For example, the difference between maxima of emission bands for solvent-free and acetonitrile-solvated forms for complex 3 amounts to 140 $\mathrm{nm}$, i.e., the color of luminescence changes from orange $(615$ $\mathrm{nm})$ to blue-green $(475 \mathrm{~nm})$. The observed hypsochromic shift of both excitation and emission bands (Table 2) denotes that coordination of the solvent changes selected metal-metal bond lengths and results in stabilization of the ground state cluster orbitals to give higher energy emission. This effect may also increase the contribution of $\pi-\pi^{*}$ transitions into emission that is evidenced by the appearance of a structure in the luminescence bands of the solvates (Figure 7). The vibronic progression of $\sim 1500 \mathrm{~cm}^{-1}$ clearly points to strong involvement of the ligand aromatics in the electron transition process responsible for the emission.

It is worth mentioning that the increase of electron-donating ability of a weakly coordinating molecule leads to growth of the hypsochromic shift of the emission maximum of the solvated form, e.g., for 3 , the value of this shift in the case of chloroacetonitrile solvate is only $28 \mathrm{~nm}$, whereas acetonitrile causes a shift of $140 \mathrm{~nm}$ (Figure 8).

Compound 6 displays only minor bathochromic shift of $\sim 6$ $\mathrm{nm}$, which is indicative of essentially a different mechanism of the solvation effect compared to that of congeners $\mathbf{1 - 5}$. This observation looks very natural taking into account occupation

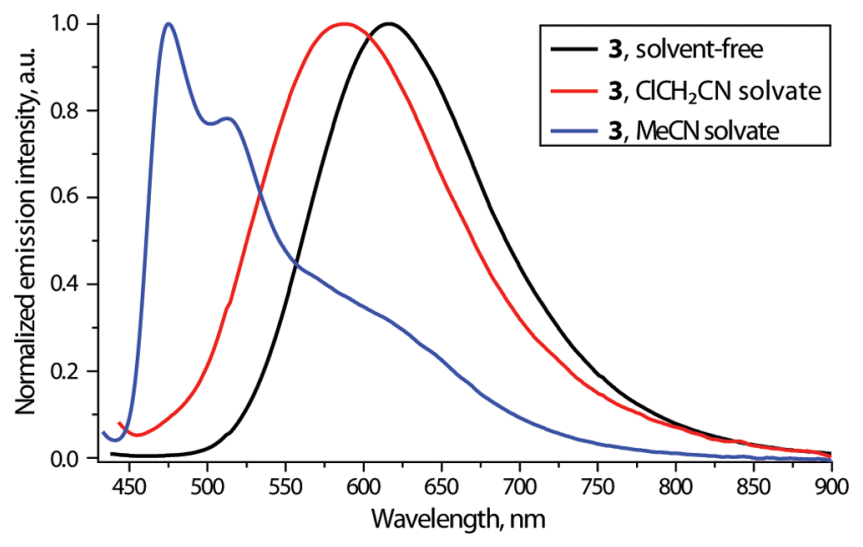

Figure 8. Emission spectra of solvent-free complex 3 and its chloroacetonitrile and acetonitrile solvates at $298 \mathrm{~K}$ in the solid state $\left(\lambda_{\text {ex }}=385 \mathrm{~nm}\right)$.

of vacant coordination sites in $\mathbf{1 - 5}$ by the pyridyl substituents of the phosphine in 6 . The structural parameters of polymorphs 6A and 6B show some minor deviations in bond lengths (see a comparative in Table S3), which are difficult to correlate however with the spectroscopic changes observed. The latter can be tentatively assigned to variations of crystal packing, e.g., similarly to the behavior of some hexanuclear gold(I) clusters. ${ }^{27}$

Computational Studies. The structural and photophysical properties of complexes 1-6 were studied using the DFT and TD-DFT approach. Note that the optimized structure of $\mathbf{6}$ is completely in accordance with the XRD data and is substantially different from those of the $1-5$ relatives due to pyridyl functions of the alkynyl ligands, leading to additional binding to copper ions and thus changing the geometry of the cluster framework.

Ground state geometrical and electronic structures of $3 \mathbf{A}$ and 3C, as representative examples, were optimized to give structural parameters of these molecules (Table S4) and a set of boundary MOs of eight low-lying excited singlet states associated with the long wavelength absorption bands, Tables S5 and S6. Structural parameters of the DFT-optimized ground states for $3 \mathrm{~A}$ and $3 \mathrm{C}$ fit well with those obtained using XRD analysis (see Table S4).

The predicted low energy absorption/excitation bands for $3 \mathbf{A}$ $\left(\lambda_{\mathrm{abs}}=362 \mathrm{~nm}\right.$, Table 3$)$ are determined by the electron transitions between MOs consisting mainly of $\pi$ orbitals (triple bond and aromatics) of the alkynyl ligands with significant admixture of the copper d-AOs (Table S5, Figure S5) and vacant LUMOs composed of related nonbonding $\pi^{*}$ orbitals and copper $\mathrm{d} / \mathrm{p}$-AOs, but the percentage of copper orbitals drops substantially at the expense of an increase in the phopshine orbitals contribution. Analysis of these data shows that the lowest energy electron transition is determined by the $\pi \rightarrow \pi^{*}$ intraligand (alkynyl) transitions with the admixture of MLCT character. The corresponding electron density difference plots are shown in Figure 9 (3A and $\mathbf{3 C}$ ) and Figure S6 (1, 2, and 4-6).

Coordination of acetonitrile ligands to $3 \mathrm{~A}$ to give solvated species $3 \mathrm{C}$ results in substantial variations in the cluster core geometry (see discussion above) accompanied by changes in the nature of the frontier orbitals accompanied by an increase in the HOMO-LUMO and HOMO(-1)-LUMO gaps (see Tables S5 and S6), which is completely in line with the experimental observations. 
Table 3. Computational Photophysical Results for Clusters $1-6^{a}$

\begin{tabular}{|c|c|c|c|}
\hline & $\lambda_{\text {abs calo }} \mathrm{nm}$ & $\lambda_{\text {em calo }} \mathrm{nm}$ & $\lambda_{\mathrm{em}}, \mathrm{nm}$ \\
\hline 1 & $\begin{array}{c}418(0.02), 409(0.33), 406(0.11) \\
379(0.08), 378(0.03), 373(0.08)\end{array}$ & 653 & 658 \\
\hline 2 & $\begin{array}{l}357(0.00), 356(0.08), 351(0.04) \\
348(0.02), 339(0.16)\end{array}$ & 624 & 621 \\
\hline $3 A$ & $\begin{array}{l}362(0.04), 354(0.19), 340(0.12) \\
329(0.06), 327(0.05)\end{array}$ & 623 & 615 \\
\hline $3 \mathrm{C}$ & $\begin{array}{c}350(0.00), 348(0.09), 342(0.12) \\
336(0.06), 332(0.05), 327(0.03)\end{array}$ & 530 & $\begin{array}{l}475,513 \\
\quad 612(\mathrm{sh})\end{array}$ \\
\hline 4 & $\begin{array}{c}381(0.01), 380(0.16), 374(0.15) \\
373(0.58), 350(0.30), 346(0.12)\end{array}$ & 652 & 624 \\
\hline 5 & $\begin{array}{c}368(0.01), 365(0.06), 363(0.02) \\
359(0.15), 345(0.16), 334(0.05)\end{array}$ & 570 & 579 \\
\hline 6 & $\begin{array}{l}450(0.00), 416(0.04), 401(0.07) \\
392(0.01), 388(0.04)\end{array}$ & 566 & $\begin{array}{l}508,546 \\
(\mathrm{sh})\end{array}$ \\
\hline
\end{tabular}

${ }^{a_{T}}$ The calculated maxima of absorption are represented by all lowest $S_{0}$ and several higher singlet states with significant $(>0.01$ in parentheses) oscillator strengths.

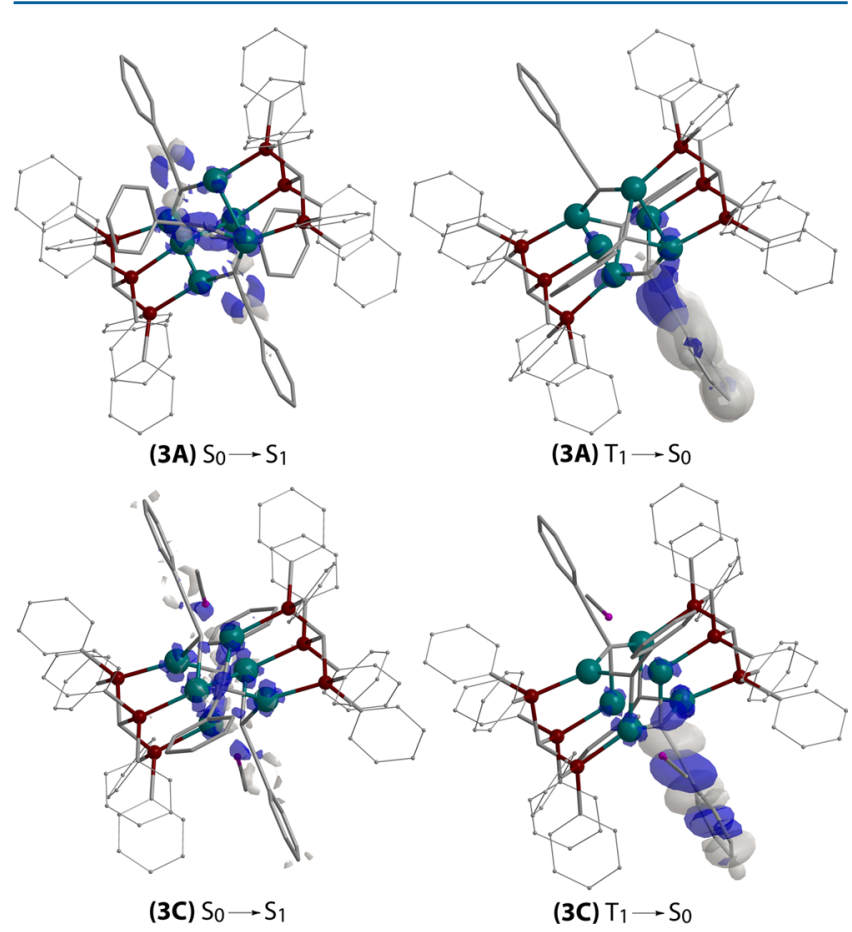

Figure 9. Electron density difference plots for the lowest-energy singlet excitation $\left(S_{0} \rightarrow S_{1}\right)$ and the lowest-energy triplet emission $\left(T_{1}\right.$ $\rightarrow \mathrm{S}_{0}$ ) of clusters $\mathbf{3 A}$ and $3 \mathrm{C}$. During the electronic transition, the electron density increases in the gray areas and decreases in the blue areas; the plots are obtained by subtracting the ground state $S_{0}$ from the excited states $\left(\mathrm{S}_{1}\right.$ and $\left.\mathrm{T}_{1}\right)$.

It is also worth noting that a significant influence of the pyridyl moiety coordination in $\mathbf{6}$ is not only onto the cluster core structure but also onto the nature of boundary MOs and spectroscopic characteristics of this complex (Table S7). The occupied highest energy orbitals of complex 6 responsible for long wavelength absorption are comprised mostly of the copper core orbitals with a small contribution of the alkynyl and phosphine ligands, whereas low lying vacant MOs are $\pi^{*}$ orbitals of the alkynyl ligand that point to the MLCT nature of the absorption/excitation bands in this case.

Optimization of the triplet excited states of 1-6 using the TD-DFT approach allowed for elucidation of the nature of singly occupied boundary MOs and calculations of their energy characteristics. The calculated values of emission wavelength are generally in a good agreement with experimental data (Table 3). The electronic structure reorganization, associated with the intersystem crossing and formation of the lowest triplet state $T_{1}$, results in appreciable Stokes shifts and distinguishable geometrical changes in the structure of the excited triplet state, which also alters the contribution of the molecular orbitals into the emissive state.

The observed emission is determined by the transition between high and low energy singly occupied MOs (HSOMO $\rightarrow$ LSOMO), which have mostly the $\pi \rightarrow \pi^{*}$ intraligand character (see Figure 9 and Tables S8 and S9). In the case of solvated 3C, this domination of IL transitions and a more rigid local environment of the alkynyls presumably accounts for the appearance of the structured emission band with a vibronic progression of $\sim 1500 \mathrm{~cm}^{-1}$ that is typical for aromatic fragments. The calculated energies of emissions also clearly show (Table 3) that complexes give appreciable blue shift of the emission bands.

\section{CONCLUSIONS}

In summary, the combination of bridging triphosphine ligand $\left(\mathrm{PPh}_{2}\right)_{3} \mathrm{CH}$ and terminal alkynes $\mathrm{HC}_{2} \mathrm{R}$ allowed for the preparation of a series of novel luminescent $\mathrm{Cu}(\mathrm{I})$ clusters $(\mathbf{1}-6)$, which were obtained in the course of self-assembly reactions in high yields. The single crystal $\mathrm{X}$-ray diffraction studies of complexes 2-5, containing $-\mathrm{C}_{2} \mathrm{C}_{6} \mathrm{H}_{4}-4-\mathrm{X}$ alkynyl groups ( $\left.\mathrm{X}=\mathrm{OMe}(2), \mathrm{H}(3), \mathrm{Ph}(4), \mathrm{CF}_{3}(5)\right)$, reveal an essentially similar $\mathrm{Cu}_{6}$ cluster framework, which adopt a distorted octahedral arrangement of the metal centers. On the contrary, employment of 2-ethynylpyridine instead of derivatives of phenylacetylene results in a dramatic change of the cluster structural motif in comparison to $\mathbf{1 - 5}$. The presence of additional coordinating functions (pyridine units) leads to an open geometry of the metal core in $\mathbf{6}$, showing a considerably smaller degree of metallophilic bonding. The ESI-MS measurements indicate that all of the title compounds retain their stoichiometry in solution, though the presence of intramolecular dynamics, assigned to the nonrigidity of the coordination environment, was detected at room and elevated temperatures by ${ }^{31} \mathrm{P}$ and ${ }^{1} \mathrm{H}$ NMR spectroscopy.

Complexes $\mathbf{1 - 6}$ are moderately luminescent in the solid state at ambient temperature ( $\Phi_{\mathrm{em}}$ up to $17 \%$ ), showing a variation of emission colors from deep-red $\left(\lambda_{\mathrm{em}}=658 \mathrm{~nm}\right.$ for 1$)$ to green $\left(\lambda_{\mathrm{em}}=508 \mathrm{~nm}\right.$ for $\left.\mathbf{6}\right)$. Interestingly, clusters $\mathbf{1 - 5}$ demonstrate a distinct and easy to detect alteration of luminescence characteristics upon exposure to the vapors of selected volatile organic compounds (acetone, acetonitrile). The observed modulation of the photophysical properties is attributed to the formation of solvates in the solid state, which was confirmed by the structural investigations. TD-DFT computational studies show that weakly coordinating solvent molecules give substantial variation in the nature and energy of the orbitals responsible for emission by increasing the contribution of the intraligand transition to give a blue shift of emission maxima and visible variation of emission color for complexes 1-5. Reversibility of the solvent absorption makes it possible to use these solid phases as sensors for a wide range of coordinating solvent vapors. 


\section{ASSOCIATED CONTENT}

\section{S Supporting Information}

The Supporting Information is available free of charge on the ACS Publications website at DOI: 10.1021/acs.inorgchem.5b00239.

Additional computational results (PDF)

Optimized Cartesian coordinates of the studied systems in atomic units (ZIP)

X-ray crystallographic data in CIF format for 2-6 (CIF)

\section{AUTHOR INFORMATION}

\section{Corresponding Authors}

*E-mail: igor.koshevoy@uef.fi.

*E-mail: stunik@inbox.ru.

\section{Notes}

The authors declare no competing financial interest.

\section{ACKNOWLEDGMENTS}

This research has been supported by St. Petersburg State University Research Grant 0.37.169.2014, and Russian Foundation for Basic Research Grants 13-03-00970, 14-0332077, and 13-03-12411. Academy of Finland (Grant 268993/ 2013, I.O.K), University of Eastern Finland (strategic funding-Russian-Finnish collaborative project), is also gratefully acknowledged. The work was carried out using equipment of the Analytical Center of Nano- and Biotechnologies of SPbSPU with financial support of the Ministry of Education and Science of Russian Federation; Centers for Magnetic Resonance, X-ray Diffraction Studies, Chemical Analysis and Materials Research, Optical and Laser Materials Research; and Computer Center of St. Petersburg State University.

\section{REFERENCES}

(1) (a) Yam, V. W.-W.; Wong, K. M.-C. Chem. Commun. 2011, 47, 11579-11592. (b) Chen, Z.-N.; Zhao, N.; Fan, Y.; Ni, J. Coord. Chem. Rev. 2009, 253, 1-20. (c) Yam, V. W.-W.; Cheng, E. C.-C. Chem. Soc. Rev. 2008, 37, 1806-1813. (d) Barbieri, A.; Accorsi, G.; Armaroli, N. Chem. Commun. 2008, 2185-2193. (e) Yam, V. W.-W.; Cheng, E. C.C. Top. Curr. Chem. 2007, 281, 269-309. (f) Omary, M. A.; Mohamed, A. A.; Rawashdeh-Omary, M. A.; Fackler, J. P. J. Coord. Chem. Rev. 2005, 249, 1372-1381. (g) Bergmann, L.; Friedrichs, J.; Mydlak, M.; Baumann, T.; Nieger, M.; Bräse, S. Chem. Commun. 2013, 49, 6501-6503. (h) Liang, J.; Chen, Z.; Yin, J.; Yu, G.-A.; Liu, S. H. Chem. Commun. 2013, 49, 3567-3569. (i) Visbal, R.; Ospino, I.; Lopez-de-Luzuriaga, J. M.; Laguna, A.; Gimeno, M. C. J. Am. Chem. Soc. 2013, 135, 4712-4715. (j) To, W.-P.; Chan, K. T.; Tong, G. S. M.; Ma, C.; Kwok, W.-M.; Guan, X.; Low, K.-H.; Che, C.-M. Angew. Chem., Int. Ed. 2013, 52, 6648-6652. (k) Hsu, C.-W.; Lin, C.-C.; Chung, M.-W.; Chi, Y.; Lee, G.-H.; Chou, P.-T.; Chang, C.-H.; Chen, P.-Y. J. Am. Chem. Soc. 2011, 133, 12085-12099.

(2) (a) Schmidbaur, H.; Schier, A. Chem. Soc. Rev. 2012, 41, 370412. (b) Lang, H.; Jakob, A.; Milde, B. Organometallics 2012, 31, 7661-7693. (c) Xie, Y.-P.; Mak, T. C. W. J. Am. Chem. Soc. 2011, 133, 3760-3763. (d) Qiao, J.; Shi, K.; Wang, Q.-M. Angew. Chem., Int. Ed. 2010, 49, 1765-1767.

(3) (a) He, X.; Yam, V. W.-W. Coord. Chem. Rev. 2011, 255, 21112123. (b) Zhou, Y.-P.; Liu, E.-B.; Wang, J.; Chao, H.-Y. Inorg. Chem. 2013, 52, 8629-8637. (c) Blanco, M. C.; Camara, J.; Gimeno, M. C.; Laguna, A.; James, S. L.; Lagunas, M. C.; Villacampa, M. D. Angew. Chem., Int. Ed. 2012, 51, 9777-9779. (d) Mo, L.-Q.; Jia, J.-H.; Sun, L.j.; Wang, Q.-M. Chem. Commun. 2012, 48, 8691-8693. (e) Koshevoy, I. O.; Chang, Y.-C.; Karttunen, A. J.; Haukka, M.; Pakkanen, T.; Chou, P.-T. J. Am. Chem. Soc. 2012, 134, 6564-6567. (f) Lasanta, T.; Olmos, M. E.; Laguna, A.; Lopez-de-Luzuriaga, J. M.; Naumov, P. J. Am. Chem.
Soc. 2011, 133, 16358-16361. (g) Koshevoy, I. O.; Karttunen, A. J.; Shakirova, J. R.; Melnikov, A. S.; Haukka, M.; Tunik, S. P.; Pakkanen, T. A. Angew. Chem., Int. Ed. 2010, 49, 8864-8866. (h) Strasser, C. E.; Catalano, V. J. J. Am. Chem. Soc. 2010, 132, 10009-10011. (i) Koshevoy, I. O.; Lin, Y.-C.; Chen, Y.-C.; Karttunen, A. J.; Haukka, M.; Chou, P.-T.; Tunik, S. P.; Pakkanen, T. A. Chem. Commun. 2010, 46, 1440-1442. (j) Jia, J.-H.; Wang, Q.-M. J. Am. Chem. Soc. 2009, 131, 16634-16635. (k) Gimeno, M. C.; Laguna, A. Chem. Soc. Rev. 2008, 37, 1952-1966. (1) Fernandez, E. J.; Laguna, A.; Lopez-de-Luzuriaga, J. M. Dalton Trans. 2007, 1969-1981.

(4) Pyykkö, P. Chem. Soc. Rev. 2008, 37, 1967-1997.

(5) (a) Lim, S. H.; Olmstead, M. M.; Balch, A. L. J. Am. Chem. Soc. 2011, 133, 10229-10238. (b) Koshevoy, I. O.; Lin, C.-L.; Karttunen, A. J.; Haukka, M.; Shih, C.-W.; Chou, P.-T.; Tunik, S. P.; Pakkanen, T. A. Chem. Commun. 2011, 47, 5533-5535. (c) Perruchas, S.; Le Goff, X. F.; Maron, S.; Maurin, I.; Guillen, F.; Garcia, A.; Gacoin, T.; Boilot, J.-P. J. Am. Chem. Soc. 2010, 132, 10967-10969. (d) Osawa, M.; Kawata, I.; Igawa, S.; Hoshino, M.; Fukunaga, T.; Hashizume, D. Chem. - Eur. J. 2010, 16, 12114-12126. (e) Ito, H.; Saito, T.; Oshima, N.; Kitamura, N.; Ishizaka, S.; Hinatsu, Y.; Wakeshima, M.; Kato, M.; Tsuge, K.; Sawamura, M. J. Am. Chem. Soc. 2008, 130, 10044-10045. (f) Katz, M. J.; Ramnial, T.; Yu, H.-Z.; Leznoff, Daniel B. J. Am. Chem. Soc. 2008, 130, 10662-10673. (g) Fernandez, E. J.; Lopez-deLuzuriaga, J. M.; Olmos, M. E.; Monge, M.; Perez, J.; Laguna, A.; Mohamed, A. A.; Fackler, J. P. J. J. Am. Chem. Soc. 2003, 125, 20222023. (h) Lee, Y.-A.; Eisenberg, R. J. Am. Chem. Soc. 2003, 125, 77787779.

(6) (a) Hau, F. K.-W.; He, X.; Lam, W. H.; Yam, V. W.-W. Chem. Commun. 2011, 47, 8778-8780. (b) Lee, T. K.-M.; Zhu, N.; Yam, V. W.-W. J. Am. Chem. Soc. 2010, 132, 17646-17648. (c) He, X.; Cheng, E. C.-C.; Zhu, N.; Yam, V. W.-W. Chem. Commun. 2009, 4016-4018.

(7) Buschbeck, R.; Low, P. J.; Lang, H. Coord. Chem. Rev. 2011, 255, $241-272$.

(8) (a) Xu, L.-J.; Wang, J.-Y.; Zhang, L.-Y.; Shi, L.-X.; Chen, Z.-N. Organometallics 2013, 32, 5402-5408. (b) Koshevoy, I. O.; Lin, Y.-C.; Karttunen, A. J.; Chou, P.-T.; Vainiotalo, P.; Tunik, S. P.; Haukka, M.; Pakkanen, T. A. Inorg. Chem. 2009, 48, 2094-2102.

(9) (a) Yam, V. W.-W.; Lee, W.-K.; Cheung, K. K.; Lee, H.-K.; Leung, W.-P. J. Chem. Soc., Dalton Trans. 1996, 2889-2891. (b) Siu, S. K.-L.; Ko, C.-C.; Au, V. K.-M.; Yam, V. W.-W. J. Cluster Sci. 2014, 25, 287-300.

(10) (a) Diez, J.; Gamasa, M. P.; Gimeno, J.; Lastra, E.; Aguirre, A.; Garcia-Granda, S. Organometallics 1993, 12, 2213-2220. (b) Yip, J. H. K.; Wu, J.; Wong, K.-Y.; Yeung, K.-W.; Vittal, J. J. Organometallics 2002, 21, 1612-1621. (c) Lo, W.-Y.; Lam, C.-H.; Yam, V. W.-W.; Zhu, N.; Cheung, K.-K.; Fathallah, S.; Messaoudi, S.; Le Guennic, B.; Kahlal, S.; Halet, J.-F. J. Am. Chem. Soc. 2004, 126, 7300-7310.

(11) (a) Naldini, L.; Demartin, F.; Manassero, M.; Sansoni, M.; Rassu, G.; Zoroddu, M. A. J. Organomet. Chem. 1985, 279, c42-c44. (b) Yam, V. W.-W.; Lee, W.-K.; Cheung, K.-K. J. Chem. Soc., Dalton Trans. 1996, 2335-2339. (c) Chan, W.-H.; Zhang, Z.-Z.; Mak, T. C. W.; Che, C.-M. J. Organomet. Chem. 1998, 556, 169-172. (d) Yam, V. W.-W.; Lo, K. K.-W.; Wong, K. M.-C. J. Organomet. Chem. 1999, 578, $3-30$.

(12) APEX2, software suite for crystallographic programs; Bruker AXS, Inc.: Madison, WI, 2009.

(13) Sheldrick, G. M. Acta Crystallogr., Sect. A: Found. Crystallogr. 2008, A64, 112-122.

(14) Farrugia, L. J. J. Appl. Crystallogr. 1999, 32, 837-838.

(15) Sheldrick, G. M. SADABS-2008/1, Bruker AXS area detector scaling and absorption correction; Bruker AXS: Madison, WI, 2008.

(16) CrysAlisPro, 1.171.36.32 (release Feb 08, 2013); Agilent Technologies.

(17) Dolomanov, O. V.; Bourhis, L. J.; Gildea, R. J.; Howard, J. A. K.; Puschmann, H. J. Appl. Crystallogr. 2009, 42, 339-341.

(18) Spek, A. L. PLATON, a multipurpose crystallographic tool; Utrecht University: Utrecht, The Netherlands, 2005.

(19) Frisch, M. J.; Trucks, G. W.; Schlegel, H. B.; Scuseria, G. E.; Robb, M. A.; Cheeseman, J. R.; Montgomery, J. A.; Vreven, T.; Kudin, 
K. N.; Burant, J. C.; Millam, J. M.; Iyengar, S. S.; Tomasi, J.; Barone, V.; Mennucci, B.; Cossi, M.; Scalmani, G.; Rega, N.; Petersson, G. A.; Nakatsuji, H.; Hada, M.; Ehara, M.; Toyota, K.; Fukuda, R.; Hasegawa, J.; Ishida, M.; Nakajima, T.; Honda, Y.; Kitao, O.; Nakai, H.; Klene, M.; Li, X.; Knox, J. E.; Hratchian, H. P.; Cross, J. B.; Bakken, V.; Adamo, C.; Jaramillo, J.; Gomperts, R.; Stratmann, R. E.; Yazyev, O.; Austin, A. J.; Cammi, R.; Pomelli, C.; Ochterski, J. W.; Ayala, P. Y.; Morokuma, K.; Voth, G. A.; Salvador, P.; Dannenberg, J. J.; Zakrzewski, V. G.; Dapprich, S.; Daniels, A. D.; Strain, M. C.; Farkas, O.; Malick, D. K.; Rabuck, A. D.; Raghavachari, K.; Foresman, J. B.; Ortiz, J. V.; Cui, Q.; Baboul, A. G.; Clifford, S.; Cioslowski, J.; Stefanov, B. B.; Liu, G.; Liashenko, A.; Piskorz, P.; Komaromi, I.; Martin, R. L.; Fox, D. J.; Keith, T.; Al-Laham, M. A.; Peng, C. Y.; Nanayakkara, A.; Challacombe, M.; Gill, P. M. W.; Johnson, B.; Chen, W.; Wong, M. W.; Gonzalez, C.; Pople, J. A. Gaussian 09; Gaussian, Inc.: Wallingford, CT, 2009.

(20) (a) Perdew, J. P.; Burke, K.; Ernzerhof, M. Phys. Rev. Lett. 1996, 77, 3865-3868. (b) Adamo, C.; Barone, V. J. Chem. Phys. 1999, 110, $6158-6170$.

(21) Weigend, F.; Ahlrichs, R. Phys. Chem. Chem. Phys. 2005, 7, $3297-3305$

(22) Schäfer, A.; Horn, H.; Ahlrichs, R. J. Chem. Phys. 1992, 97, 2571-2577.

(23) (a) Furche, F.; Rappoport, D., Density Functional Methods for Excited States: Equilibrium Structure and Electronic Spectra. In Computational Photochemistry; Olivucci, M., Ed.; Elsevier: Amsterdam, 2005; pp 93-128. (b) Furche, F.; Ahlrichs, R. J. Chem. Phys. 2002, 117, 7433-7447. (c) van Wüllen, C. J. Comput. Chem. 2011, 32, $1195-1201$.

(24) O’boyle, N. M.; Tenderholt, A. L.; Langner, K. M. J. Comput. Chem. 2008, 29, 839-845.

(25) Farrugia, L. J. J. Appl. Crystallogr. 2012, 45, 849-854.

(26) (a) Makal, A.; Benedict, J.; Trzop, E.; Sokolow, J.; Fournier, B.; Chen, Y.; Kalinowski, J. A.; Graber, T.; Henning, R.; Coppens, P. J. Phys. Chem. A 2012, 116, 3359-3365. (b) Zink, D. M.; Volz, D.; Baumann, T.; Mydlak, M.; Flugge, H.; Friedrichs, J.; Nieger, M.; Brase, S. Chem. Mater. 2013, 25, 4471-4448. (c) Cid, J.-J.; Mohanraj, J.; Mohankumar, M.; Holler, M.; Accorsi, G.; Brelot, L.; Nierengarten, I.; Moudam, O.; Kaeser, A.; Delavaux-Nicot, B.; Armaroli, N.; Nierengarten, J.-F. Chem. Commun. 2013, 49, 859-861. (d) Dau, T. M.; Shakirova, J. R.; Karttunen, A. J.; Grachova, E. V.; Tunik, S. P.; Melnikov, A. S.; Pakkanen, T. A.; Koshevoy, I. O. Inorg. Chem. 2014, 53, 4705-4715. (e) Hofbeck, T.; Monkowius, U.; Yersin, H. J. Am. Chem. Soc. 2015, 137, 399-404.

(27) Koshevoy, I. O.; Chang, Y.-C.; Chen, Y.-A.; Karttunen, A. J.; Grachova, E. V.; Tunik, S. P.; Jänis, J.; Pakkanen, T. A.; Chou, P.-T. Organometallics 2014, 33, 2363-2371. 